\title{
CONSTRUCTING THE FIELD OF PROFESSIONAL RESPONSIBILITY
}

\author{
JANE B. BARON* \\ \& Richard K. GREenSTEIN**
}

INTRODUCTION $\ldots \ldots \ldots \ldots \ldots \ldots \ldots \ldots \ldots \ldots \ldots \ldots \ldots \ldots \ldots \ldots \ldots$

I. The Law School Construction of Professional

RESPONSIBLITY .......................... 41

A. The Construction of Law in the Law School

Curriculum............................ 41

B. The Construction of Professional Responsibility as a Field of Law ......................... 47

II. The Contingency of the Construction ........ 59

A. Framing the Issues...................... 63

B. Applying the Law .................... 68

III. Some Observations about the "Field" of

Professional Responsibility ................ 73

A. The Allure of the Law School Construction of

Professional Responsibility ................. 75

1. Promises of the Law School Construction.. 75

a. Freedom from Sanctions ............. 76

b. Freedom from Moral Accountability ....... 79

2. The Indeterminacy Problem .......... 82

a. The Indeterminacy of Professional

Responsibility Doctrine ............. 83

b. The Indeterminacy of the Moral Justification of the Adversary System .............. 85

c. The Indeterminacy of the Standard Conception of the Lauyer's Role......... 86

d. The Indeterminacy of Act Description ...... 88

B. Three (or Four) Constructions of the Field ........ 89

Conclusion ................................. 96

\section{INTRODUCTION}

This paper begins from the observation of what seems an odd phenomenon: the role of lawyer is widely understood by law

* Professor of Law, Temple University.

** Professor of Law, Temple University. We wish to thank Alice Abren, Jeffrey Dunoff, Theresa Glennon, and Eleanor Myers for comments and suggestions on earlier drafts. Temple University School of Law provided research support, for which we are grateful. 
students and practitioners as the entry into a simplified ethical world, one in which ordinary moral principles are cleared away by the hegemony of doctrines unique to the practice of law. Taking on the special obligations of the lawyer is not thought to add to one's moral burdens, but, paradoxically, to render large parts of the role morally simple, or even amoral. As we are not the first to notice, these understandings are supported by and may originate in a particular view of lawyers' professional responsibilityview in which a lawyer's ethical obligations as a professional are defined largely (though not entirely) by specialized legal rules (principally the codes of ethics and other rules that regulate lawyer conduct) and the policies thought to underlie those rules. Like drivers on the road who must contend with duties imposed by the law of torts, or like businessmen whose transactions must take account of the law of contracts, lawyers in their everyday work must comply with what some call the "law of lawyering."

There is nothing natural or even intuitive about defining lawyers' ethical obligations primarily in terms of compliance with rules. Indeed, there has long been a debate about whether black letter codifications can possibly serve as an adequate platform for ethical deliberation. ${ }^{1}$ But to acknowledge this debate is not to argue that there is some alternative way of thinking about lawyers' professional responsibility that is truly or actually natural. All "fields" of law must be constructed somehow. ${ }^{2}$ What is worth consideration is how a field is constructed in one way rather than another, and the effects of any given construction.

Our thesis embraces two claims. The first claim is that within the traditional law school curriculum, law is constructed as a relatively autonomous "discipline" distinguished from other disciplines, including philosophical ethics, and that the discipline of law is subdivided into relatively separate "fields." Thus, notwithstanding more than a century of developments in legal education and claims of "progress" in our understanding of law-notwithstanding the academy's apparent absorption of influences ranging from legal realism to critical legal studies to

1. See, e.g., Richard L. Abel, Why Does the ABA Promulgate Ethical Rules?, 59 Tex. L. Rev. 639 (1981); Heidi Li Feldman, Codes and Virtues: Can Good Lauyers Be Good Ethical Deliberators?, 69 S. CAL. L. REv. 885, $900-07$ (1996); Tanina Rostain, Ethics Lost: Limitations of Current Approaches to Lawyer Regulation, 71 S. CAL. L. REv. 1273 (1998).

2. The "field" of property, for example, was once constructed almost entirely around the English common law system of estates in land, but it is less so today, whenever less wealth is held in the form of real property. See John $\mathrm{H}$. Langbein, The Twentieth-Century Revolution in Family Wealth Transmission, 86 Mich. L. Rev. 722 (1988). See also Joseph William Singer, The Reliance Interest in Property, 40 Stan. L. Rev. 611 (1988). 
feminist jurisprudence to critical race theory to a host of "law and" analyses-students continue to be educated into a relatively Langdellian world view. ${ }^{3}$ The second claim is that within the traditional law school curriculum, professional responsibility is constructed as its own field of law-a reality perfectly captured in the title of one of the leading professional responsibility casebooks: Cases and Materials on the Law Governing Lawyers. ${ }^{4}$ As a consequence, law students learn to think of law, generally, and professional responsibility, specifically, as disengaged from moral considerations.

Our observations about these issues come from outside the field. Neither of us teaches professional responsibility, ${ }^{5}$ nor have we heretofore produced scholarship addressing issues of professional responsibility. Accordingly, we take no position on the many important debates within the field about lawyers' particular ethical responsibilities. As outsiders, we are interested in how the field appears to be constructed and what strikes us as some of the implications of that construction.

As outsiders we are also well aware that we are not the first to observe the uneasy relationship between ethics and the field of professional responsibility. Countless scholars, attorneys, teachers, and students have wrestled with the question of how the parameters of the lawyer's role should be understood in light of ordinary morality. Our contribution to this ongoing debate, we hope, is to describe how the "legalistic" construction of professional responsibility has been systematically built into the typical law school curriculum. So powerful is this construction that important attempts to teach against it have marginal effect, and casebooks in the field that challenge the construction are rarely used. Indeed, such is the hegemony of this construction that its most basic component-the separation of the field of professional responsibility from ethics-is reinforced by even the most thoughtful and influential dissident voices in the scholarship of the field.

3. For a succinct statement of Langdell's view of law as a science, see Christopher C. Langdell, A Selection of Cases on the LaW of Contracts vvii (1871), reprinted in Readings in tHe History of tHe AMERICAN Legal ProfessION 216-17 (Dennis R. Nolan ed., 1980); Christopher C. Langdell, Teaching Law as a Science, 21 Am. L. Rev. 123 (1887). See generally Thomas C. Grey, Modern American Legal Thought, 106 YALE L. J. 493 (1996) (book review); Thomas C. Grey, Langdell's Orthodoxy, 45 U. PrTt. L. Rev. 1 (1983).

4. James E. Moliterno, Cases and Materials on the Law Governing LAWYERS (2000).

5. We do co-teach a law school course, Ethical Perspectives on the Practice of Law, which touches on many of the issues raised in this essay. 
Part I of this paper takes up the question of how the professional responsibility field has been traditionally structured in the law school curriculum, exploring the ways in which professional responsibility has been constructed on a "legalistic" model, i.e., as but another field of law. This model teaches students to view professional ethics as a body of rules, doctrines, and principles promulgated by authoritative institutions and to view an analysis of issues within this field as an application of methods of legal reasoning, understood to be distinct from the ordinary modes of moral reasoning. This curricular construction responds to a variety of pressures ranging from more general beliefs about the nature of law, to the law schools' perceived responsibility to help students pass the Multistate Professional Responsibility Examination, to students' expectations about what they should be learning in a professional school. The overall effect of the legalistic model is to inculcate what we call a "pothole" conception of ethics, in which ethical issues are understood as "problems" and "dilemmas" which lie along the otherwise morally smooth road of legal practice and which the attentive lawyer can anticipate and either avoid or safely negotiate.

In Part II we point out that there is nothing about the concept of law that requires its separation from ordinary moral reasoning. Law could be (and has been) understood instead to be inextricably tied to morality. We suggest that when law is constructed so as to be saturated with moral concerns, then the professional work of lawyers and, hence, their professional responsibilities, can be understood to be similarly saturated. We do this by examining the routine tasks of lawyering: decisions as to whether and how to litigate a particular case, the framing of legal issues, the presentation of facts, interpretive judgments about the meaning of legal doctrine, and what application to particular facts. These tasks are often presented in legal education as matters of craft and strategy, but, we argue, they can be seen as suffused with moral significance. We do not argue that law must or even should be seen as suffused with moral significance, only that it can be. Our point is that this alternative view of the possible connection between law and morality might suggest a very different vision of the field of professional responsibility.

In Part III we explore some of what is at stake in our decisions about how to construct professional responsibility. We begin by observing that the traditional law school construction, with its separation of professional responsibility doctrine from ordinary moral principles, has a powerful allure for law students and practitioners, and we examine the basis for that allure and its remarkable resiliency in the face of repeated, multidimensional 
assaults on the legalistic model. We then turn to a curious fact about the Langdellian model of law as a separate, distinct, and even autonomous field: it seems to define not only the traditional legalistic model of professional responsibility, but some of the most important alternatives to that model that have emerged in recent decades. Accordingly, we examine what kind of understanding of ourselves as lawyers is built into the general idea of constructing professional responsibility as a field of law, and we ask what kind of self-understanding might flow from constructing professional responsibility instead as an expression of ordinary morality.

We want to emphasize that this essay offers no new alternative model on which to construct professional responsibility. Our concern is to describe how the traditional, dominant model is systematically expressed in the law school curriculum, generally, and in the professional responsibility curriculum, specifically, and to explore some of the implications of the model's hegemony. At the same time, we do not regard this essay as simply an academic exercise, and we readily acknowledge the strong criticism of the traditional construction implied in the discussion that follows, a point to which we will return in the Conclusion.

\section{The Law School Construction of Professional Responsibility}

\section{A. The Construction of Law in the Law School Curriculum}

When we say that professional responsibility is constructed as a "field of law," we mean this initially ${ }^{6}$ in the sense that contracts, torts, property, and so forth are constructed as fields of law within the law school curriculum. For reasons that we will discuss below, there are substantial pressures to make professional responsibility look like other law school courses and, hence, to make the "field" of professional responsibility look like other "fields" included in the curriculum. ${ }^{7}$ It is important, therefore, to be clear about how a legal field is typically constructed in law school, especially in the first year, when students' understanding of law is most acutely shaped.

The salient characteristic of law's construction in the academy is its disciplinary separateness. That is, law is understood to be a discrete discipline, an area of study distinct from, say, sociol-

6. See discussion infra Part III.B.

7. See discussion infra Part III.A. 
ogy, literature, economics, or political science. 8 This is not to deny the potential significance of these other disciplines for legal thought. Indeed, principally under the lingering influence of Legal Realism, the relevance of extra-legal disciplines, perhaps most notably economics, is widely acknowledged within the academy. Nonetheless, and this is crucial, these influences are typically understood as distinct from law itself.

An important aspect of this disciplinary separateness is the claim that law involves a distinctive way of reasoning about legal issues: "thinking like a lawyer." Indeed, among the powerful tools in the construction of law as an autonomous discipline is the idea that law demands a distinctive way of thinking, one that is different from ordinary reasoning. ${ }^{9}$ And one of the principal ways in which it is different from ordinary reasoning is its banishment of sentiment, emotion, and ordinary moral consideration from the analysis of legal doctrine and the application of doctrine to concrete legal disputes (legal disputes being a distinct species of dispute). Notwithstanding relentless criticism from sectors of the academy, ${ }^{10}$ students are typically discouraged from

8. For a discussion of the construction of law as a discipline in the context of the law-and-literature movement, see Jane B. Baron, Law, Literature, and the Problems of Interdisciplinarity, 108 YALE L.J. 1059 (1999).

9. As Professor Kingsfield put it in the film The Paper Chase, "You come here with minds full of mush-and leave thinking like a lawyer." THE PAPER Chase (20th Century Fox 1973); see also John Jay Osborn, JR., The Paper Chase 17-21 (1971). Or, as one of us was told on the first day of law school, "Cherish this moment! It is the last time you will think like a human being."

This feature of the law school construction of law has a significant ideological overlay. The "objective" and "neutral" Rule of Law contrasts with rules in accordance with the personal and subjective wishes of the powerful. See generally Joseph William Singer, The Player and the Cards: Nihilism and Legal Theory, 94 YALE L.J. 1 (1984). Hence, because sentiment, emotion, and moral consideration are deemed to reflect personal and subjective interests and preferences, their relationship to legal reasoning is highly problematic. For arguments that "legal reasoning" is a unique and distinctive form of thinking, the elements of which can be taught and learned, see StEVEN J. Burton, AN INTRODUction To Law and Legal Reasoning (2d ed. 1995); Richaro B. Cappalli, The American Common Law Method (1997); Kenneth J. Vandevelde, Thinking Like a LawYER: AN INTRODUCTION TO LEGAL REASONING (1996).

Of course, as with all aspects of the law school construction, there are dissenters. See, e.g., infra note 10. Moreover, Western legal thought includes important constructions of law-natural law theory, and the Jewish and Islamic legal traditions stand out as examples-that link law inextricably to morality.

10. See, e.g., Thomas L. Shaffer \& Robert F. Cochran, Jr., Lawyers, Cuients, and Moral Responsibility (1994); Roger I. Abrams, The Dance and the Adjudication of Disputes, 51 Rutgers L. Rev. 901 (1999); Martha C. Nussbaum, Skepticism about Practical Reason in Literature and the Law, 107 HARV. L. REv. 714 (1994); Marjorie A. Silver, Love, Hate, and Other Emotional Interference in the Lawyer/Client Relationship, 6 CuINICAL L. Rev. 259 (1999). 
expressing emotional discomfort with a line of analysis or from criticizing a decision on the grounds that it is simply immoral.

The separateness of law extends to the individual doctrinal areas that constitute the study of law. Notwithstanding experiments aimed at breaking down the borders separating Langdell's doctrinal divisions, ${ }^{11}$ torts, contracts, and property are typically constructed in the law school curriculum as distinct fields, each with its own terminology, mode of analysis, and logical separation from other fields. ${ }^{12}$ Thus, part of the rigor of legal inquiry involves breaking down the genus of law into sharply differentiated species, which are then treated as natural kinds. ${ }^{13}$

What are entering law students taught about the moral dimensions of their professional work? If we examine the standard first-year curriculum, we find an array of doctrinally oriented courses (typically torts, contracts, property, constitutional law, criminal law, and civil procedure), a course in legal research and writing, and perhaps one in legal methods. We find nothing in the standard first-year curriculum that takes justice or ethics as its specific subject matter.

In the doctrinal courses, students are exposed, primarily through the study of cases and statutes, to the concepts that define the field. In contracts, for instance, they learn the requirements for contract formation, the affirmative defenses that can be raised to escape contractual obligations, and the remedies available for breach. Initially, these concepts are perceived as bits of information to be learned and memorized, and the techniques of case analysis and statutory interpretation that are practiced along the way are seen as tools for ferreting out these pieces of doctrine.

However, in time, students come to understand that the lawyer's job is not to mechanically apply doctrine to facts and crank

11. The experimental curriculum of CUNY Law School and the alternative first-year curriculum at Harvard are examples. On the CUNY curriculum, see Howard Lesnick, Infinity in a Grain of Sand: The World of Law and Lawyering as Portrayed in the Clinical Teaching Implicit in the Law School Curriculum, 37 UCLA L. Rev. 1157 (1990); on the Harvard curriculum, see Todd D. Rakoff, The Harvard First-Year Experiment, 39 J. Legal Educ. 491 (1989). See also Jay Feinman \& Marc Feldman, Pedagogy and Politics, 73 GEo. L.J. 875, 900-25 (1985) (discussing their course in Contorts).

12. See, e.g., Alabama Great S. R.R. Co. v. Carroll, 11 So. 803 (Ala. 1892) (rejecting a contract characterization in favor of a tort characterization); Haumschild v. Continental Cas. Co., 95 N.W.2d 814 (1959) (rejecting a tort characterization in favor of a family law characterization).

13. Consequently, the infiltration of analysis characteristic of another doctrinal field-for example, the replacement of a property analysis of landlord-tenant relationships with a contract analysis-tends to be slow. 
out the correct answers. They learn that the holdings of cases can be read narrowly or broadly; that by focusing on different aspects of two cases, they can analogize or distinguish them; and that a series of cases can be synthesized in different ways. They learn that a statutory text can be interpreted in accordance with its plain meaning or purpose or with the intent of its framers, and that this variety of interpretive approaches can be further complicated by irresolvable disagreements over what constitutes the plain meaning or the legislative intent or the statute's purpose. And from this process, students come eventually to see that legal doctrine is not a compilation of bits of information to be learned and memorized, but malleable concepts characterized by a significant degree of vagueness and open texture. ${ }^{14}$

With this insight comes power. Once the student of contract law sees that the doctrine of consideration has a lot of play in the joints, she understands that in many cases it will be possible for a lawyer to argue either that there is or is not legally adequate consideration. Once the student of criminal law understands that the doctrines of insanity, involuntariness, and provocation overlap, she understands that in many cases it will be possible for a lawyer to frame a defense in a variety of ways. ${ }^{15}$

But the power is not unlimited. Students learn that they cannot argue anything they want. Within a doctrinal area, legal argumentation is constrained by the policies that are conventionally understood to inform the field. Fault and compensation in torts; freedom of contract, reliance, and fair dealing in contract

14. On the concept of open texture, see infra text accompanying note 98 .

15. Through the legal research and writing course, the first-year student will also learn that factual descriptions of cases are similarly malleable. Specifically, she develops the skill of crafting a "Statement of the Case" in briefs that will set the stage for the chosen issue formulation and supporting legal arguments. Student attitudes toward the development of these manipulative skills vary. Some students understand themselves to be mastering a powerful esoteric logic called "legal reasoning." Others will understand themselves to be mastering the moves of an elaborate game. Many who share the view that there is a distinctly "legal" form of reasoning have argued that the techniques of such reasoning have a structured or patterned quality, in which arguments can be, and often are, paired in ways that, in effect, cancel each other out, rather than leading to single correct answers. For examples of such skeptical approaches, see Pierre Schlag \& David Skover, Tagtics of Legal Reasoning (1986); James Boyle, A Symposium of Critical Legal Studies: The Anatomy of a Torts Class, 34 Aм. U. L. Rev. 1003, 1051-60 (1985); Laura E. Little, Characterization and Legal Discourse, 46 J. Legal Educ. 372, 383-92 (1996); Jeremy Paul, The Politics of Legal Semiotics, 69 Tex. L. Rev. 1779, 1786 (1991). For a legal realist version of this point in connection with statutory construction, see Karl N. Llewellyn, Remarks on the Theory of Appellate Decision and the Rules or Canons About How Statutes Are to be Construed, 3 VAND. L. Rev. 395 (1950). 
law; retribution and utility in criminal law; efficiency, accuracy, and fairness in procedure-each of these sets of values forms a matrix within which issues are framed and doctrinal arguments made and which determines the persuasiveness of these framings and arguments. ${ }^{16}$ For example, there will be many contract cases in which the lawyer cannot plausibly argue that consideration is lacking. ${ }^{17}$

Where in all this learning is instruction in the ethical dimensions of the lawyer's role? In an important sense, it is everywhere in the first-year curriculum but as an absence. That is, most of the curriculum is instruction as to what the practicing lawyer is not morally accountable for. And the instruction is almost never explicit.

To the extent that students perceive doctrine to have a moral dimension, they understand that moral dimension to reside in the creation of law by legislatures, courts, administrative agencies, and constitutional conventions. It is, for instance, of considerable moral significance whether a product manufacturer can be held liable for injuries caused in the absence of fault. It is a similarly great moral question whether a signatory to a contract can escape the accepted obligations on the grounds that the terms are unconscionable. But the value judgments reflected in these doctrines are made by legislators, including common law judges. Law students learn from the outset that as advocates, they are not accountable for the moral choices reflected in the contours of legal doctrine. They learn this through the persistent presentation of doctrine as emanating from sources external to the lawyer-from cases, statutes, regulations, and constitutional provisions. In this model of law, morality may affect the decisions that lead to law's creation, but it is largely irrelevant to disputes about what the current state of the law is and how it applies to specific cases. Judges, legislators, administrators, and constitutional framers are responsible for creating doctrine. They make the law; lawyers only make arguments.

Of course policy-so much a part of standard legal analysis-can be understood to raise dramatic moral issues. ${ }^{18}$ Policies

16. See generally Richard K. Greenstein, The Nature of Legal Argument: The Personal Jurisdiction Paradigm, 38 Hastings L.J. 855 (1987).

17. Whether this limitation is an intrinsic property of law or is the product of institutional or external forces has been widely debated. See, e.g., J.M. Balkin, Ideology as Constraint, 43 STAN. L. Rev. 1133 (1991) (reviewing ANDREW Altman, Critical Legal. Studies; A Liberal Critique (1990)); Singer, supra note 9, at 19-25. See generally, Duncan Kennedy, Freedom and Constraint in Adjudication: A Critical Phenomenology, 36 J. LeGal EdUC. 518 (1986).

18. See discussion infra Part II.B. 
concern the purposes and consequences of particular legal doctrines, and the relationships among consequentialist analysis, morality, and law have long been identified and explored. ${ }^{19}$ Indeed, the policies that inform the various doctrinal fieldsautonomy, retribution, fair dealing, efficiency, fault-based liability, compensation, and so forth-reflect important considerations of social justice that are continually in play among the cases studied in first-year courses. It is not uncommon for these values to be identified and discussed in the law school classroom. Students might be encouraged, for instance, to debate whether the law of torts ought to recognize some kind of an affirmative duty to rescue other members of the community who are in danger. But law school pedagogy distinguishes between such conversations about the wisdom of policies and the lawyer's craft in making any of a number of competing policy arguments, depending on what is required to further the interests of the client. Like doctrine, policies are presented as external to the lawyer. The lawyer finds policies in the opinions of judges, in legislative history, in statutory preambles, and in the public and private writings of the Constitution's framers. Lawyers make use of policies-lawyers might even propose new policies-but the responsibility for choosing among competing policies, lawyers are taught, is once again that of law makers. In sum, for the law student, policies are not expressions of moral considerations, but additional weapons in the strategic armory available to the lawyer to further the client's goals.

And what about the "play in the joints"? Might not the power to frame the issue, to construe the doctrine, to present the facts, or to apply law to facts in this way or that,- - might not this power entail an ineradicable moral dimension and consequently an unavoidable moral responsibility on the part of the lawyer? It might. ${ }^{20}$ But that is not what first-year law students are taught. The relentless practice of argumentation skills throughout that initial year is justified in terms of craft, and the choices to be made regarding the content of arguments are governed largely by strategic concerns, that is, concerns that center on advancing the client's interests. In classroom interactions, whether the student argues for the prevailing conceptions or for a change in the law; whether she frames the issue narrowly or broadly; whether she argues for a statute's plain meaning or for an interpretation that will carry out its putative purpose; whether she analogizes or

19. See, e.g., Jeremy Bentham, An Introduction to the Principles of Morals and Legislation (1789).

20. See discussion infra Part II. 
distinguishes a particular precedent-all these choices, she comes to understand, turn on two considerations: what can be plausibly maintained and what will serve the client's interests and goals. Rarely, if ever, are these choices explicitly recognized by teacher or student to express moral decisions for which the lawyer is accountable.

This silence reinforces the instrumentalist conception of the lawyer's role that law students have already absorbed from the larger culture. This is the conception of the lawyer as the client's hired gun, champion, gladiator, and paladin. This instrumentalist conception-often dubbed the "standard conception" comprises the notion of lawyer neutrality (the lawyer does not judge the client's goals) and partisanship (the lawyer uses all of his craft to further those goals within the bounds of the law, including the law of professional responsibility). ${ }^{22}$

An important corollary of the neutral partisanship conception is moral nonaccountability. ${ }^{23}$ Insofar as he uses his craft to further the goals of the client, the lawyer is not accountable if those goals lack moral worthiness (measured by ordinary morality), and insofar as his use of his craft is lawful, he is not accountable if the means lack moral worthiness (again, measured by ordinary morality). As we will see in Part III, part of the allure of constructing law as a distinct, bounded field, separate from other disciplines, including philosophical ethics, is its apparent ability to shore up this assertion of moral nonaccountability. ${ }^{24}$

\section{B. The Construction of Professional Responsibility as a Field of Law}

What, then, does the first-year law student take to be the subject matter of legal ethics? To the extent that the course work or hallway conversation involves any discussion of a lawyer's ethical obligations, it most likely amounts to unsystematic references to various ethical problems that a lawyer might encounterproblems involving matters, such as keeping client confidences and avoiding conflicts of interest. These problems have little to do with what the student has come to see as the lawyer's core work: analyzing cases, interpreting statutes, framing issues, organizing facts, and making arguments. They have everything

21. See David Luban, Lawyers and Justice: An Etrical Study 393-403 (1988); see also Gerald J. Postema, Moral Responsibility in Professional Ethics, 55 N.Y.U. L. Rev. 63, 73 (1980), reprinted in ETHICS AND THE Legal Profession 158, 165 (Michael Davis \& Frederick A. Elliston eds., 1986) [hereinafter ErHICs].

22. For an extensive analysis of the important role that the standard conception actually plays, see LUBAN, supra note 21 , at 393-403.

23. See id. at 154-56.

24. See discussion infra Part III.A. 
to do with discrete problems arising out of specific relationships between the lawyer and others: the lawyer and the client, the lawyer and a tribunal, the lawyer and third parties. In sum, the depiction of the moral landscape in legal practice shows that practice to be largely unencumbered by ethical concerns, but for occasional potholes in the road-danger areas that the conscientious and attentive lawyer should either avoid altogether or navigate through carefully and safely.

To accomplish this safe navigation, the first-year student is assured that she will draw on the same skills applicable to the competent mastery of doctrine. What any student is likely to hear early and often is the responsibility of the lawyer to zealously represent the client "within the bounds of the law." 25 Perhaps only dimly at first, the student comes to understand that the "bounds of the law" not only refers to the law of crimes, torts, and contracts, but also to the law of legal ethics. A perusal of the curriculum reveals that there is a course that addresses that law. Like torts, contracts, property, and the like, professional responsibility is treated as a body of doctrine to be specially studied and mastered-in this case through an upper-level course.

To construct professional responsibility as law in the way that law is generally constructed in the law school curriculum means constructing it as an autonomous field-one that is sharply distinguished from other subjects in the curriculum and from other "extra-legal" fields such as philosophy, economics, and sociology, and one in which problems are subjected to a reasoning process that excludes sentiment, emotion, and moral consideration. Now, the idea that moral considerations should be regarded as extraneous to the field of professional responsibility

25. This language was included in Canon 15 of the A.B.A. Canons of Professional Ethics, adopted in 1908:

In the judicial forum the client is entitled to the benefit of any and every remedy and defense that is authorized by the law of the land, and he may expect his lawyer to assert every such remedy or defense. But it is steadfastly to be borne in mind that the great trust of the lawyer is to be performed within and not without the bounds of the law.

The Canons were superseded in 1969 by the A.B.A. Model Code of Professional Responsibility, Canon 7 of which holds that "[a] lawyer should represent a client zealously within the bounds of the law." The language does not appear in the mandatory provisions of the A.B.A.'s 1983 Model Rules of Professional Conduct, in the "Comment" on Rule 1.3 (Diligence), the Model Rules state that the lawyer:

May take whatever lawful and ethical measures are required to vindicate a client's cause or endeavor. A lawyer should act with commitment and dedication to the interests of the client and with zeal in advocacy upon the client's behalf. However, a lawyer is not bound to press for every advantage that might be realized for a client. 
might seem counterintuitive. After all, "Legal Ethics" is an occasionally used alternative name for this particular curricular offering. But the construction of the doctrinal field of legal ethics must be viewed in the context of the overall construction of law. Law, as we have seen, is constructed in the curriculum as positive law, as law emanating from an authoritative, political source. Accordingly, professional ethics as a field is constructed as positive legal doctrine emanating from authoritative, political sources, principally bar associations and courts. Notwithstanding powerful dissenting voices, ${ }^{26}$ ethics in the more common sense of moral philosophy is treated as a different kind of matter in the standard construction of the field-different because morality is presented as personal and subjective and thus not properly a part of any field of law, including the law of professional responsibility.

This dichotomy is nicely captured by William Simon:

There are two prevailing conceptions of legal ethics or professional responsibility. The first conflates legal ethics with the disciplinary rules of the codes-rules promulgated under state-delegated authority and enforced by punitive sanctions. Under this conception, the subject might better be called "Regulation of Lawyers," a name in fact used by one of the legal ethics textbooks, in the same way that the study of the rules governing the practice of transportation companies is called "Regulation of Common Carriers." The second conception conflates legal ethics with the private or personal moralities of individual lawyers. Here the core concerns are the constraints of role on self-expression and the legitimacy of requiring the individual lawyer to perform actions in role that conflict with her personal values.

The disciplinary rule conception is the dominant one among lawyers and law teachers. Most law school courses and bar association discussions of legal ethics are devoted largely to such rules. The professional responsibility component of bar exams consists entirely of a test of such rules. The personal morality conception is the dominant one among philosophers and psychologists concerned with lawyering, and it has influenced a minority of law teachers and practitioners as well, including most of those with the more original and ambitious approaches to legal ethics.

26. See Luban, supra note 21; Postema, supra note 21; Richard Wasserstrom, Lawyers as Professionals: Some Moral Issues, 5 Human Rights Q. 105-28 (1975), reprinted in ETHICS, supra note 21, at 114-31. 
These people try to help lawyers become more self-conscious and articulate about their personal values and to provide some psychological support for such values against the pressures of role. ${ }^{27}$

As Simon goes on to observe, the Model Rules, which form the doctrinal skeleton for most, if not all, professional responsibility courses, draws from each of these conceptions:

On the one hand, there are norms designed for disciplinary enforcement prohibiting specified conduct. Although the drafters of the Model Rules describe these norms as "rules of reason," most of them in fact have a rigid, categorical character that leaves little room for judgment, and in fact these norms were designed, as one drafter put it, "to provide a black letter rule for every case." On the other hand, we find a set of norms that effectively grant broad, unreviewable autonomy to lawyers to consult their personal values. These norms are typically contentless; they make no effort to suggest how the decisions that fall under them might be made other than in terms of the lawyer's subjective predispositions. ${ }^{28}$

An example of Simon's point is the Model Rules' provision regarding termination of representation. On the one hand, Rule 1.16 lists three specific instances in which the lawyer is required to withdraw from representation: when the representation will result in violation of the law, when "the lawyer's physical or mental condition materially impairs the lawyer's ability to represent the client, or when the client discharges the attorney." ${ }^{29}$ By contrast, the lawyer is permitted to withdraw when "a client insists on pursuing an objective that the lawyer considers repugnant ...."30 The latter provision is noteworthy both because of its permissive, rather than mandatory character (no sanctions attach to the lawyer's decision in this regard), and because the question of repugnance is dependent on what "the lawyer considers" to be the case-that is, repugnance is a matter of the lawyer's personal sensibilities, not an ethical quality of the client's objective.

This law-morality dichotomy plays an important structural role within the Model Rules. The "Preamble" identifies a number of criss-crossing ethical obligations: obligations to the client, to

27. William H. Simon, The Trouble With Legal Ethics, 41 J. Legal Educ. 65, 65-66 (1991) (citations omitted).

28. Id. at 67 (citations omitted).

29. Model Rules of Professional Conduct Rule 1.16(a)(1)-(3) (1983).

30. Id. Rule 1.16(b) (3). 
legal institutions, to third parties, and to the public. It goes on to recognize that it is in the "nature of law practice" that:

[C] onflicting responsibilities are encountered. Virtually all difficult ethical problems arise from conflict between a lawyer's responsibilities to clients, to the legal system and to the lawyer's own interest in remaining an upright person while earning a satisfactory living .... ${ }^{31}$

But an examination of the rules reveals that these "conflicting responsibilities" do not all take place within the law. Rule 2.1 provides:

In representing a client, a lawyer shall exercise independent professional judgment and render candid advice. In rendering advice, a lawyer may refer not only to law but to other considerations such as moral, economic, social and political factors, that may be relevant to the client's situation. $^{32}$

This language indicates two things: first, that reference to "moral" factors is distinguished from references to the "law"; second, that the rendering of moral advice is permissive, rather than mandatory. These points are both elaborated in the "Comment" that follows the Rule:

[2] Advice couched in narrowly legal terms may be of little value to a client, especially where practical considerations, such as cost or effects on other people, are predominant. Purely technical legal advice, therefore, can sometimes be inadequate. It is proper for a lawyer to refer to relevant moral and ethical considerations in giving advice. Although a lawyer is not a moral advisor as such, moral and ethical considerations impinge upon most legal questions and may decisively influence how the law will be applied. ${ }^{33}$

This distinction between authoritatively promulgated mandatory rules of conduct and personal, subjective morality is reflected in the National Conference of Bar Examiners' characterization of its Multistate Professional Responsibility Examination (M.P.R.E.). The Conference describes the M.P.R.E. as:

[B]ased on the law governing the conduct of lawyers, including the disciplinary rules of professional conduct currently articulated in the ABA Model Rules of Professional Conduct, the ABA Model Code of Judicial Conduct, as well as controlling constitutional decisions and generally

31. Id. Preamble.

32. Id. Rule 2.1.

33. Id. Rule $2.1 \mathrm{cmt}$. 
accepted principles established in leading federal and state cases and in procedural and evidentiary rules. . . .

The purpose of the [MPRE] is to measure the examinee's knowledge and understanding of established standards related to a lawyer's professional conduct; thus, the MPRE is not a test to determine an individual's personal ethical values .... ${ }^{34}$

The M.P.R.E. is a multiple-choice test, presenting the examinee with factual situations, each of which is followed by a question requiring application of the norms of professional conduct. The examinee is instructed to "pick the best answer from the four possible answer choices" provided for each question. ${ }^{35}$ The majority of questions specifically test knowledge of the disciplinary rules and doctrines that would subject a lawyer to discipline, sanction, disqualification, or civil or criminal liability. While some questions ask what is "proper" conduct on the part of a lawyer, the instructions do not ask the examinee to determine what is proper through moral reasoning, but rather to apply authoritatively promulgated standards and "generally accepted principles."

The construction of professional responsibility as a field of law, characterized by the separation of law and morality typical of the law school construction of fields of law generally, is directly and clearly signaled in the primary teaching materials available on the market for professional responsibility courses. These materials are, almost without exception, casebooks, taking exactly the form of the teaching materials used in conventionally legal fields of property, contracts, torts, and so forth. ${ }^{37}$ Like the books developed for these other areas, the casebooks in professional responsibility often include a good deal of material other than cases-snippets from news articles, paragraphs from law journal

34. National Conference of Bar Examiners, THe MPRE (Multistate ProFESSIONAL RESPONSIBILITY EXAMination): 2000 INFORMATION BOOKLET 2, 26 (1999).

35. Id. at 28.

36. Id.

37. Some books are more unconventional than others, and probably more idiosyncratic than most is John T. NoOnan, JR. \& RICHaRd W. PainTer, Professional and Personal Responsibilities of the Lawyer (1997). Yet even Noonan and Painter's highly unconventional (and sparsely adopted) book is built around cases, though their choice of cases is fairly unusual. The principal exception to the casebook model is Nathan M. Crystal, Professional Responsibility: Problems of Practice and the Profession (1996), which consists entirely of problems and text, with no reproduced cases. 
pieces, or excerpts from books. ${ }^{38}$ But also like those other books, the professional responsibility casebooks clearly signal that these are extra-legal materials. They belong to philosophy, sociology, political science, economics, or some other non-legal field. They are not law. The fundamental presumption-and the message for students-is that professional responsibility is a field of law, to be taught and learned exactly as any other field of law, by reference to distinctly legal materials which contain or explicate the relevant doctrinal principles. ${ }^{39}$

Moreover, the casebooks focus on law, i.e., the constellation of regulatory provisions to which lawyers must conform their conduct. The object seems largely to expose students to the rules in force relating to the principal professional responsibility issues of confidentiality, competence, loyalty, and zealous advocacy. Most books focus on the Model Rules or the Model Code, indeed, the stronger the focus on the rules, the better the book seems to sell. ${ }^{40}$ Of course, the rules-focus of most of the more

38. See, e.g., Richard A. Zitrin \& Carol M. Langford, Legal Ethics in THE Practice of Law (1995). The authors state:

We follow each problem with a series of readings. . . . Many of these readings are cases, excerpts of law review articles, formal ethics opinions, or our own analysis. But many of the readings are more colloquial-accounts from legal periodicals, or newspaper accounts from the popular press. We consider all these readings to be of equal importance. Certain readings provide more black letter analysis, while others are more important for making the ethical principles more accessible and easier to grasp, or for providing a strong dose of practicality.

Id. at 3 .

39. See, for example, Stephen Gillers, Regulation of Lawyers: Problems of Law and Ethics 1 ( $5^{\text {th }}$ ed. 1998), the first words of which are: "As the Preface cautioned, 'legal ethics' is something of a misnomer for the subject of this book and the courses likely to use it.... What you are studying is the law governing lawyers." Id. Robert F. Cochran, Jr. \& Teresa S. Collett, Cases and Materials on the Rules of the Legal Profession v (1996) opens as follows:

The focus of this casebook is on the rules of the legal profession. We focus on the rules of the profession because they are important. The rules establish minimum standards for lawyers. They establish a framework within which lawyers operate. Their importance to lawyers and law students is obvious: violations of the rules may subject lawyers to professional disapproval, discipline, fines, procedural sanctions, and, Id. in some cases, liability.

40. The more traditional, rule-oriented books outsell their less conventional rivals by considerable margins. As one publisher's representative put it:

Of our books, the MORGAN \& Rotunda [infra note 43], easily the most traditional, continues to be the most popular with adoptions at over 75 schools each year. The HAZARD, Koniak \& CRAmTOn [infra note 46] 
popular books does not preclude the use of the supplementary, "enrichment" materials described above. Yet, those materials appear, as they do in casebooks in other legal fields, to explicate the "policy" aspects of the professional responsibility. Like contracts, with its (potentially conflicting) policies of facilitating wealth-maximizing transactions and protecting reliance, and like torts, with its (potentially conflicting) policies of penalizing fault and spreading costs, the regulatory law of professional responsibility is understood to be based on (potentially conflicting) policies to which it is important that students be exposed, such as the policy to promote open communication between lawyer and client and the policy to promote the truth-finding function of trials. These policies, like the policies in the other established legal fields, are presented as internal to the field, conflicts within the law itself, and not as instantiations of larger social problems in the "real" world. They help the student or lawyer understand the ambiguities of the existing rules, and they provide the basis for arguments about how the rules should be interpreted, but, like the rules themselves, they are presented as givens, as pieces of the existing regulatory structure that attorneys must master.

This typical structure of professional responsibility casebooks reinforces a message about the relationship between professional responsibility and "ethics"-a message typically delivered in their prefaces, introductions, or opening chapters. Almost every one of the leading casebooks begins by considering the relationship between professional responsibility or legal ethics, on the one hand, and "ethics" on the other. With rare exception, ${ }^{41}$ the books sharply distinguish legal ethics from "ethics"

has a wider scope (rules plus related legal doctrine, criminal statutes, fiduciary responsibility) of coverage than [MORGAN \& ROTUNDA] and usually numbers adoptions at $40+$ law schools. The more philosophical of the books have a smaller audience. In part this is due to expressed student resistance to this type of approach.

E-mail from Paul Thomson, Foundation Press, to Jane B. Baron (June 21, 2000) (on file with author) (citation alterations added).

Reports from other major publishers are consistent. The GiLlers casebook (see supra note 39) is adopted at over four times as many schools as the less conventional CRYSTAL book (see supra note 37). E-mail from George J. Serafin, Aspen Law and Business, to Jane B. Baron (June 21, 2000) (on file with author). See also e-mail from Peter R. Hinsch, West Publishing, to Jane B. Baron (June 22,2000 ) (reporting that the most traditional books far outsell the less traditional books) (on file with author).

41. See, e.g., NoOnan \& Painter, supra note 37, at ix. But this book has been adopted for use in only a dozen professional responsibility courses, as compared to the more traditional MORGAN \& RoTUNDA book, described infra note 43, which has over 100 adoptions. E-mail from Paul Thomson, Foundation Press, to Jane B. Baron (June 21, 2000) (on file with author). 
(the latter term nearly always appearing, as we have put it here, in quotation marks), and they explain why the two fields bear only the most tenuous of connections. For those who understand the field in fundamentally regulatory terms, i.e., as an "expression of the limits of conduct by people acting in the role of lawyer," it follows almost axiomatically that "being morally good or morally bad is not the primary inquiry" in the field. ${ }^{42}$ Of course, philosophy can be "useful" in this view, but only as a means of showing that "uncritical applications of the text of the Model Rules and Code to a problem are . . not enough," ${ }^{43}$ or as a possible source to which to turn if "there is 'no rule on point;", or when "the rule on point is so 'open textured' that you need more guidance"; or when "the rule on point permits or requires conduct that seems morally repugnant."44 But however useful philosophy might be, the reader of these casebooks clearly understands that it is not law.

Some books are quite cynical about the divide between legal and philosophical ethics, explaining that "the profession hopes to trade on the ideal of [philosophical] ethics, but it has not especially appealed to classical ethical principles in elaborating the rules governing the behavior of lawyers." ${ }^{45}$ Other books

42. Moliterno, supra note 4. Moliterno's book begins by explaining that "above all else, the law governing lawyers is law. It must be studied and mastered like any other law field." Id. at 1 (emphasis added).

43. Thomas D. Morgan \& Ronald D. Rotunda, Professional Responsibility: Problems and Materials 13 (7th ed. 2000). For Morgan and Rotunda, "ethics" is clearly in the background, while the law of lawyering is in the foreground: "The dilemma for any course such as this one is how to acknowledge philosophical traditions while recognizing that most questions of modern legal ethics are debated in more traditional legal terms." Id. (emphasis added). In the view of these authors, philosophy can be helpful, in a sort of hints-from-Heloise way, by contributing distinctions such as that between complying with minimum standards and attaining ideal behavior or between "what we want a lawyer to do and the kind of person we want a lawyer to be." Id. at 14-15. The authors clearly conceptualize law as a separate field: "legal ethics' offers an unusually good opportunity to apply the insights of history, sociology, economics and philosophy to fundamental legal questions." Id. at 2.

44. Mortimer D. SchWartz, Richard C. Wydick ANd ReX R. Perschbacher, Problems in Legal Ethics 5 (4th ed. 1997).

45. Gillers, supra note 39, at 9. Gillers, like Moliterno, believes that the subject of professional responsibility is the legal regulations governing lawyers. "Legal ethics," he states, "is something of a misnomer for the subject of this book and the courses likely to use it. . . What you are studying is the law governing lawyers." See also id. at xxii ("Here [in this book] you learn the rules you have to live by and the consequences if you ignore them."). Gillers admits that in the last two decades, ethicists and legal academics have looked at lawyers' ethics in light of moral philosophy, but he is dubious about the impact of such inquiries on the field. 
seem more wistful about the gap between "ethics" and "legal ethics." One such book explains that because philosophical ethical norms are "cast as universals in which all others are entitled to equal respect and consideration," they are not truly suited to the actual practice of law: "Rules of legal ethics are not universal because they give a preferred position to clients; the office of lawyer begins with having to make distinctions among persons." 46 The notion here seems to be that it would be wonderful if there were a larger overlap between "legal ethics" and "ethics," but, sadly, such an overlap is not truly possible.

Even the rare book that asserts a connection between legal and philosophical ethics ${ }^{47}$ underscores the fundamental difference between them. Consider, for example, the following statement:

The study of codified ethical rules apart from broader ethical principles runs the risk of superficiality: legal codes of personal conduct that ignore the moral commitments of the people they govern are doomed to irrelevance. On the other hand, a purely philosophical study of legal ethics that ignores the institutional and doctrinal basis of law practice cannot succeed. ${ }^{48}$

The principal message here is that neither the law governing lawyers nor philosophical ethics can be studied in isolation. But there is a less obvious message as well-that there is a purely philosophical realm, separate, independent and distinguishable from the legal realm of doctrine and institutional practice context. Presumably the latter is the distinct domain of legal ethics. "Ethics" and legal ethics may be connected, but the two realms do not-and apparently cannot-collapse into one.

So far there has been little cross-fertilization, as a practical matter, between the philosophical and the professional enterprises .... Moral philosophers may teach at law schools and influence law teachers, but they have not yet been invited to join the profession's ethicswriting committees .... So while the philosophers are not going to go away and are in fact becoming more influential in the academy, the force of their influence on the courts and the practicing bar has yet to be determined.

Id. at 10 .

46. Geoffrey C. Hazard, Jr., Susan P. Konlak, and Roger C. Cramton, The LaW and Ethics of Lawyering 3 (3d ed. 1999).

47. See, e.g., Deborah L. Rhode \& David luban, Legal Ethics 3 (2d ed. 1995) ("In a broader sense, . . . legal ethics is simply a special case of ethics in general, as ethics is understood in the central traditions of philosophy and religion.").

48. Id. 
In sum, the separation of law and morality that characterizes the law school construction of law generally applies specifically to the construction of professional responsibility as a field of law. This separation, which is a dimension of law's autonomy, is complemented by the tendency (noted above) of the law school curriculum to separate fields into discrete subject matters. Thus, professional responsibility is typically taught in its own course. Professional responsibility, accordingly, is defined as something different from torts, contracts, criminal law, civil procedure, or property.

That is not to deny points of intersection. Professional responsibility norms are often triggered by the contractual aspects of the lawyer-client relationship or the misappropriation of client property. In addition, violation of those norms can result in civil or criminal liability. More to the point, issues of professional responsibility can arise in the drafting of a contract, the litigation of a personal injury case, or the representation of a criminal defendant. However, as they are constructed in the law school curriculum, one can (and frequently does) study torts, contracts, criminal law, and so forth without ever addressing professional responsibility issues.

Put differently, professional responsibility is not understood to be intrinsic to these other fields. Rather, it is intrinsic to its own object of concern: the practice of law. ${ }^{49}$ Accordingly, at least in the first year of law school, a sharp distinction is made between the kinds of doctrinal questions that lawyers frequently addressquestions of interpreting statutes, synthesizing cases, drawing analogies and distinctions, framing issues, characterizing facts, among many others-and ethical "problems" and "dilemmas" which can arise in the course of legal practice. ${ }^{50}$ The former questions are properly explored in each substantive law school course. They have cognitive and practical dimensions, but have

49. See, e.g., GiLlers, supra note 39 ("Other courses teach lessons that bear on your clients' problems. This course is for you."); MORGAN \& ROTUNDA, supra note 43 , at 1 (" $[\mathrm{T}]$ he subject of the course in professional responsibility is the legal profession itself. Law students may use the substance of their torts course periodically, but they will use the substance of professional responsibility daily. This course is about lawyers as they engage in the practice of law."); ZITRIN \& LANGFORD, supra note 38, at 1-2 ("[T] he goal of this volume . . is to help you prepare for the ethical dilemmas you will certainly face as a practicing lawyer.").

50. Of course, later in law school, when students take the course in professional responsibility, they will learn to perform on professional responsibility rules the same doctrinal moves (interpretation, synthesis, etc.) they learned to perform on the rules of property, contracts, and the like. For further discussion of this point, see infra text accompanying notes 110-13. 
neither a moral dimension (because law is different from morality) nor a professional responsibility dimension (because professional responsibility is a different field). ${ }^{51}$ In them lies the heart of the lawyer's craft, which is constructed as ethically neutral in character. And as a field of law, professional responsibility has its own doctrinal concerns: ethical problems and dilemmas-i.e., the ethical potholes that lie along the otherwise morally smooth road of legal representation.

But at the same time, professional responsibility is a field of law and therefore shares with other legal fields an affinity for a distinctively legal form of reasoning. Thus, the same techniques used to interpret and apply the law of torts or the law of trusts and estates are appropriate for interpreting and applying the law of professional responsibility.

Among those who resist this separation, a common response is to call for the "pervasive" teaching of professional responsibility. ${ }^{52}$ But the pervasive method amounts largely to the teaching of generic professional responsibility issues (loyalty, confidentiality, competence, and so forth) as applied to various areas of practice. That is, professional responsibility's doctrinal concerns continue to be constructed as practice issues, not matters intrinsic to the various doctrinal fields. Even a somewhat ambitious approach, such as Scott Burnham's approach to teaching ethics in the contracts course ${ }^{53}$ can easily fall into this pattern. Thus, the ethical issues raised by Burnham generally involve situations when the lawyer might be tempted to lie,$^{54}$ to withhold important information, ${ }^{55}$ to shape the client's sworn statement,${ }^{56}$ to try

51. There are, of course, important exceptions in law school curricula throughout the United States. Consider, for example, the "Integrated Transactional Program" at Temple University, which combines instruction in the normally separate fields of trusts and estates, business law, and professional responsibility, along with instruction in drafting, interviewing, negotiation, and counseling. For a description of this program, see Eleanor W. Myers, Teaching Good and Teaching Well: Integrating Values with Theory and Practice, 47 J. LegaL EDuc. 401 (1997).

52. See, e.g., Scott J. Burnham, Teaching Legal Ethics in Contracts, $41 \mathrm{~J}$. Legal Educ. 105 (1991); Robert N. Covington, The Pervasive Approach to Teaching Professional Responsibility: Experiences in an Insurance Course, 41 U. Colo. L. Rev. 355 (1969); Ian Johnstone \& Mary Patricia Treuthart, Doing the Right Thing: An Overview of Teaching Professional Responsibility, 41 J. Legal EduC. 75, 87-89 (1991); Deborah L. Rhode, Ethics by the Pervasive Method, 42 J. Legal Educ. 31 (1992).

53. See generally Burnham, supra note 52.

54. See id. at 112, 115-16 (misrepresenting negotiating position or misrepresenting facts in an answer in order to raise statute of frauds).

55. See id. at 112-15 (withholding knowledge of law, facts, mistakes in transcribing agreements). 
to get away with what she understands to be legally impermissible. $^{57}$ These examples are not particular to contract doctrine, but are instances in a particular context of temptations generally present throughout the practice of law.

Moreover, pervasive approaches can easily replicate the lawmorality dichotomy reflected in the Model Rules. Consider Burnham's statement of his "Goals and Objectives":

My goals for teaching ethics in Contracts are to (1) detect ethical problems, (2) apply the Code or Rules to the problem, (3) recognize the limitations of the Code or Rules, and

(4) resolve the problem based on personal morality .... ${ }^{58}$

We can see in Burnham's approach precisely the structure identified by Simon. Professional ethics comprises mandatory rules on the one hand and personal morality on the other. Morality remains outside the law of professional responsibility.

\section{The Contingency of The Construction}

It is important to understand that law need not be constructed in a way that separates law and morality into two distinct fields. Indeed, much jurisprudential ink has been spilled in attempts to figure out just what role morality plays in ordinary legal reasoning. ${ }^{59}$

If, in contrast to the traditional and still standard law school construction, we were to construct law as inextricably intertwined with morality, such a construction would have an important

56. See id. at 111-12 (coaching the client with respect to the content of an affidavit).

57. See id. at 118-19 (inclusion in a contract of unenforceable exculpatory clause).

58. Id. at 108.

59. See, e.g., Lon L. Fuluer, THe Morality of LAw (rev. ed. 1969) (from a perspective that combines natural law and legal process theories); H.L.A. HART, LAW, LIBERTY AND MORALITY (1963) (from a positivist perspective). For noteworthy debates on the law-morality problem, see the exchange between Fuller and Hart: H.L.A. Hart, Positivism and the Separation of Morals, 71 HARV. L. Rev. 593 (1958) and Lon L. Fuller, Positivism and Fidelity to Law-A Reply to Professor Hart, 71 HARV. L. REv. 593, at 630 (1958); and the exchange between Fuller and Ernst Nagel: Lon L. Fuller, Human Purpose and Natural Law, 3 Natural. LAw Forum 68 (1958) and Lon L. Fuller, A Rejoinder to Professor Nagel, 3 Natural. LAw Forum 68, at 83-104 (1958).

Of course, there are systems within the Western legal tradition that understand law and morality to be intimately joined. Classical natural law is one such system. See, e.g., Thomas Aquinas, Summa Theologica, Question 90, 4th Article, in Introduction to St. Thomas Aquinas 615 (Anton C. Pegis ed., 1948). The Jewish legal tradition is another. See, e.g., Adin Steinsaltz, The Essential TALMUD, 200-201 (1976). 
implication for professional responsibility. For if the materials of law are understood to be moral materials, and if legal reasoning is understood to be moral reasoning, then all lawyering activities necessarily have moral significance. ${ }^{60}$ And every lawyer's task will raise ethical issues.

To see this, let us consider the manipulative techniques discussed earlier. Lawyers are accustomed to a certain degree of "play" in the operation of legal rules. Some legal rules are purposely phrased, not in hard edged, bright line, crystalline terms, but instead as muddy, imprecise standards (e.g., "reasonableness") that virtually invite arguments over how they should be applied. ${ }^{61}$ Even bright line rules have immanent but unwritten purposes that may contradict their literal terms. Facts can be characterized in dramatically different ways-as innocent misunderstandings or culpable misstatements, for example. And these illustrations could be multiplied through all the diverse tasks in which lawyers engage, from drafting agreements through trying cases in court. There would be little to negotiate in the drafting process if existing rules clearly and unequivocally allocated risks to one party or another; there would be little to argue about in court if both the facts and the law were transparently clear. ${ }^{62}$

60. For an especially sophisticated illustration that works out this idea, see William H. Simon, The Practice of Justice: A Theory of Lawyers' Ethics (1998). Simon employs a Dworkinian understanding of an autonomous law that incorporates a rich mix of moral principles. Accordingly, he argues that "[1] awyers should take those actions that, considering the relevant circumstances of the particular case, seem likely to promote justice." Id. at 138 . Simon goes on to say:

"Justice" here connotes the basic values of the legal system and subsumes many layers of more concrete norms. Decisions about justice are not assertions of personal preferences, nor are they applications of ordinary morality. They are legal judgments grounded in the methods and sources of authority of the professional culture. I use "justice" interchangeably with "legal merit." The latter has the advantage of reminding us that we are concerned with the materials of conventional legal analysis; the former has the advantage of reminding us that these materials include many vaguely specified aspirational norms.

Id. As we suggest, Simon's reliance on the field-of-law model perpetuates some of the law-morality problems inherent in that model. See infra text accompanying notes 125-37.

61. See Duncan Kennedy, Form and Substance in Private Law Adjudication, 89 Harv. L. Rev. 1685 (1976); Carol M. Rose, Crystals and Mud in Property Law, 40 Stan. L. Rev. 577 (1988), reprinted in Perspectives on Property LaW 320 , 320-21 (Robert C. Ellickson et al. eds., 2d ed. 1995).

62. In the traditional law school construction, lawyers construct strategies to advance their clients' interests by routinely finding and exploiting these open spaces of the law. 
But what fills the interstices of law? If legal rules are even a bit indeterminate, and the "play" with which lawyers are familiar suggest that they are, then what determines the outcome of disputed cases? There is no consensus within either academia or the bar on the answer to this question. ${ }^{63}$ Some would argue that the care with which arguments are crafted makes the difference, so that between equally plausible legal positions the judge will choose the one that has been presented better (but of course what constitutes "better" is not always clear). Others would argue that when the legal arguments are equally balanced it is policy that determines the outcome (although policy arguments may be equally balanced as well). Still others would argue that judges always retain some range of discretion and that, in exercising that discretion, their personal preferences (which may or may not be "political" in nature) will be brought into play. Certainly, it is common practice for attorneys to research prior opinions written by the judge on legal issues similar to the one at hand in order to predict what the judge "likes" to hear in such cases.

We offer no resolution to this debate. As we suggested earlier, however, part of what fills the interstices of rules could be morality. We say "part" because we do not mean to deny that quality of presentation, policy argumentation, awareness of the judge's decisional patterns, or any of a number of other factors may affect the outcome of cases. We assert only that one dimension of legal indeterminacy can be moral. That is, the interstices of law create space for moral, as well as other concerns to be considered.

63. Until the twentieth century, this quality of law was not especially controversial. Theorists from Aquinas to Langdell understood and embraced it. (Indeed, the law school tradition of "Socratic dialogue" exploits this very feature of law.) But first the Legal Realists and then legal scholars associated with Critical Legal Studies (CLS) were understood to suggest that law's "indeterminacy" gave judges room, in effect, to do anything they wanted and/or to impose their personal political preferences in deciding cases-political preferences that generally advanced the interests of the economically, socially, and politically powerful. Putting aside the question whether anyone within CLS truly made such a claim, see Balkin, supra note 17; Robert W. Gordon, Critical Legal Histories, 36 StAN. L. Rev. 57 (1984), the experience of most lawyers is quite different. It is the experience of limited freedom to maneuver within a fairly tight space. That is, the rules are perceived to limit dramatically the arguments that can be made and the facts that can be plausibly argued to be relevant (so that, for example, it would not be permissible to argue or to decide that a party should lose a case simply because of his race), but the rules are also perceived to leave considerable space for lawyers to argue about the proper outcome. For a detailed explanation of how legal rules can both limit and open space for legal arguments, see Greenstein, supra note 16. 
If we construct law this way, the manipulative techniques learned by law students take on an interesting character. Technical decisions, such as how to frame the "issue" in a case, or even whether to regard a set of facts as a "case" at all, have nontrivial moral dimensions.

Consider a prosecutor who must decide whether to bring charges against a man who is alleged to have raped a woman after a date. The evidence shows that the woman went out with the man voluntarily and consented to accompany him back to his apartment. At this point, the man's and the woman's version of events diverge, with the woman claiming the man forced her into sexual intercourse and the man claiming that the two had consensual "rough sex." The technical dimensions of the prosecutor's decision are fairly obvious, involving factors, such as whether the conduct in question can plausibly be argued to be within the scope of the applicable rape statute, whether there is independent evidence to support either party's account of the events, whether the woman (or the man) is likely to be perceived sympathetically by a jury, and so forth. Unfortunately, the ethical dimensions of the prosecutor's decision do not scan as easily. Yet, assuming that the local statute, like most rape statutes, could be read to reach the man's actions, then the prosecutor must decide whether it ought to be argued to reach them, i.e., whether the state should be seeking to discourage conduct of this kind, and this decision clearly has a moral dimension. And if the prosecutor decides not to bring the case because he thinks based on experience in the community that conviction is unlikely, this decision has a moral dimension as well, for it effectively endorses the community's existing understandings of what is tolerable and intolerable between men and women.

Sometimes the moral dimensions of ordinary, technical, legal decisions are obvious. When the prospective client is the Ku Klux Klan seeking to march in Skokie, Illinois, most observers will recognize that the decision whether to take the case is, in some respects, a moral one. In the majority of cases, however, the moral dimensions of the decisions to be made are much less obvious. Here, the invisibility of moral issues is often confused with their absence. Moreover, if we suppose that moral considerations can saturate the porous texture of the law, then not only does the decision whether to handle a particular case or pursue a particular prosecution take on moral significance, but other activities that constitute the lawyer's craft do so as well. Here are two examples: framing issues and applying the law. 


\section{A. Framing the Issues ${ }^{64}$}

Most lawyers and law professors would include the ability to "frame the legal issue" among the technical skills that law students should master. It is well understood that the framing of the issue affects which rules and facts will be deemed relevant, as well as what remedies might be available. Thus, when a client approaches an attorney with a "problem," the attorney will immediately begin to categorize the problem (civil/criminal, contract/tort, etc.), sort through the client's narrative of events for doctrinally important facts (color of leaves on trees, not important; color of traffic light at accident scene, important), and anticipate the legal problems (the "issues") that might stand in the way of the client obtaining the result she or he seeks. So, for example, if a client describes a contract dispute, but the lawyer believes there was no consideration on the facts as the client recounts them, the lawyer might probe for additional facts concerning the client's reliance on the other party's conduct, and then "frame the issue" in terms of the more doctrinally sustainable theory of promissory estoppel. If there is truly a consideration problem, the promissory estoppel framing is just good lawyering because it makes legally irrelevant the absence of a bargained-for exchange between the client and the opposing party. (The really good lawyer might also try to characterize the facts in a way that demonstrates that there actually was a bargained-for exchange, even though that exchange is not readily apparent.)

Lawyers understand that there are many ways to frame an issue. Indeed, they understand an important element of their craft to be their sense, based on intuition and experience, of which framing will be most effective. That is, they experience themselves as having to make choices about how to frame the issue. They do not tend to understand that choice as a moral one.

But let us examine two actual cases, Dothard v. Rawlinson ${ }^{65}$ and $U A W v$. Johnson Controls. ${ }^{66}$ Both cases involved Title VII challenges to employer policies that excluded women, but not men, from certain jobs in prisons (Dothard) and in battery manufacturing plants (Johnson Controls). In both cases, the issue was framed

64. The examples used in this section and the one that follows are drawn exclusively from litigation. This bias simply reflects our backgrounds and the types of problems with which we are most familiar. We are confident that the very points we are exploring in this Part could be made, mutatis mutandis, in transactional and other nonlitigation contexts.

65. 433 U.S. 321 (1977).

66. 499 U.S. 187 (1991). 
as whether the exclusionary policy in question could be justified as a "bona fide occupational qualification" (B.F.O.Q.). The Court held in Dothard that the policy of excluding women from contact positions in men's maximum security prisons could be justified as a B.F.O.Q., but it held in Johnson Controls that the policy of excluding women from lead-exposure jobs in battery manufacturing plants could not be justified as a B.F.O.Q.

On conventional analysis, the female plaintiff lost in Dothard and won in Johnson Controls. From a feminist perspective, certainly, there is much to dislike about Dothard. The Court held that a female employee's "very womanhood would ... . directly undermine her capacity" to perform her responsibilities as a prison guard. ${ }^{67}$ This sort of statement presumes both that women have some sort of essential nature and that that nature is, in certain contexts, disabling or inferior. On the other side, in Johnson Controls, the Court seemed to affirm women's capacity to make important decisions for themselves; it held that "it is no more appropriate for the courts than it is for individual employers to decide whether a woman's reproductive role is more important to herself and her family than her economic role. Congress has left this choice to the woman as hers to make." 68 And on a practical, as well as a rhetorical level, Johnson Controls seems a better decision for the plaintiff, and for the other women the plaintiff represented, ${ }^{69}$ than Dothard, for in the former case the jobs in question were opened up to women, whereas in the latter the jobs remained closed.

Yet, on reflection, it is not clear how to judge either case. Had the women plaintiffs prevailed in Dothard, they would have had the privilege of working anywhere in Alabama's prison system, a system whose conditions were described by the Supreme Court as "peculiarly inhospitable . . . for human beings of whatever sex" and by a federal District Court as characterized by "rampant violence" and a "jungle atmosphere."70 Meanwhile, the women plaintiffs who prevailed in Johnson Controls gained the privilege of working in jobs that posed a clear danger not only to their own reproductive health, but to the health of any fetus they might carry during their employment. ${ }^{71}$ It is not obvious why the

67. 433 U.S. at 336.

68. 499 U.S. at 211.

69. Both suits were class actions.

70. 433 U.S. at 334.

71. "Respondent Johnson Controls, Inc., manufactures batteries. In the manufacturing process, the element lead is a primary ingredient. Occupational exposure to lead entails health risks, including the risk of harm to any fetus carried by a female employee." 499 U.S. at 190 . 
loss of an opportunity to work in conditions potentially violative of the Eighth Amendment should be lamented, nor obvious why the acquisition of an opportunity to work in conditions injurious to health should be celebrated.

The problem in both of the cases derives from the way the issue was framed. In each case, the background conditions in which the women would work were left unquestioned. ${ }^{72}$ In Dothard, the Court asked, in effect, whether, in prisons that were already extremely violent, it would be safe to have women in contact positions with prisoners. In Johnson Controls, the Court asked, in effect, whether, in a manufacturing process that exposed workers to high levels of lead, it was legitimate to exclude women in order to preserve their reproductive health. The Court did not ask the critical questions: why the prisons were violent or why battery workers were exposed to such high levels of lead. These questions are not unthinkable nor obvious only in hindsight. The prison conditions assumed in Dothard were under direct attack even as the Court rejected the plaintiffs' claims. And while there was no analogous suit challenging the manufacturing procedures assumed in Johnson Controls, the question of tort liability was raised in connection with the B.F.O.Q. defense, so the reasonableness of the existing battery manufacturing process could not have been entirely out of the Court's mind.

The effect of the framing of the issue was and is not trivial. It subjected the plaintiffs and those they represented to a loselose proposition in which if they won, they would be in danger; and if they lost they would be denied choices men were free to make. This framing has a moral dimension. The lawyers who brought both suits arguably applied their talents to making their clients' lives dangerous-successfully in the case of Johnson Controls. It is surely not self-evident that putting one's client at risk of physical harm is a morally correct thing to do. And, physical danger aside, there were other serious risks inherent in framing the issue in terms of parity with men. Such a framing, as feminists, such as Catherine MacKinnon have long pointed out, creates the standard that women must aspire to whatever it is that men have $;^{73}$ if men can work in lead exposure jobs without regard to fertility, women can; if men can work in contact positions in rampantly violent prisons, women can, too. Asking that women be

72. On the technique of reframing issues so as to move questionable (but unquestioned) assumptions from the background to the foreground, see Duncan Kennedy, A CRITIQUe of Adjudication (FIN de SIECle) 24749 (1997).

73. See, e.g., Catherine A. MacKinnon, Difference and Dominance: On Sex Discrimination, in Feminism UnModified: Discourses ON LIFE AND LAW 32 (1987). 
treated like men may be a reasonable way to advance their interests, but then again, it may not. The decision to go in this direction is more than simply tactical. If women ask to be treated as men are treated in instances where (as in the case of pregnancy) women seem to be different, they effectively invite courts to engage in a compare-and-contrast exercise in which women may well be judged inferior. ${ }^{74}$ To a feminist, the Court's characterizations of women and "womanhood" in Dothard seem downright silly, but most people do not read Supreme Court opinions with a feminist eye. To them, the Court's characterizations may seem both accurate and authoritative. Again, it is not self-evident that putting one's client at risk of being deemed inferior is a morally correct thing to do.

One standard response to these observations is that, notwithstanding the moral dimensions of the framing problem, the lawyer bears no personal moral responsibility because in the end it is the court that determines what the issue is and how to resolve it. While it may be comforting to think that the judge will somehow "fix" framing problems, it is hardly realistic. Judges are not free simply to ignore the issues the parties bring before them and instead tell parties that they should bring some different sort of action for some different relief. While the Court is undoubtedly responsible for its own rhetoric in Dothard, and while the plaintiff's lawyer may not have anticipated that the Court would react to the case as it did, it does not follow that the lawyer is, for those reasons, not accountable for the rhetorical and practical results reached in the case. Once the issue is framed in terms of women's capacity to serve in contact positions in prisons, the lawyer cannot control the outcome, and an insulting finding of incapacity becomes possible as a direct result of the way the attorney has framed the case.

But, it might be argued, what if the plaintiffs in Dothard and Johnson Controls wanted to be treated the same as men, and asked their lawyers to file suit seeking equal treatment? Isn't it the lawyer's obligation to carry out the client's expressed wishes, allowing the client to make the critical choices about what ends to seek? These questions are important, but they dramatically oversimplify the relationship between client and attorney. Clients do not come to lawyers with "cases," but with human problems. It is highly unlikely that the plaintiffs in Dothard or Johnson Controls entered into their lawyers' offices specifically ask-

74. There is substantial literature on the sameness-difference debate. See, e.g., Feminist Jurisprudence: The Difference Debate (Leslie F. Goldstein ed. 1992). 
ing the lawyers to file a class action under Title VII of the Civil Rights Act of 1964 or talking of B.F.O.Q.s. It is far more likely that they simply described their experiences seeking the jobs they wanted. It is the lawyer who "constructs" or "transforms" the facts the client supplies into a legal "case." N5 Nor is it true, in the instances where several different kinds of cases could be brought to remedy the problem with which the client approached the attorney, that the choice of which possible course to pursue is made primarily (let alone solely) by the client. Lawyers repeatedly note that the manner in which they present choices to the client has a dramatic impact on what the client chooses to do. ${ }^{76}$ Since there is no completely neutral way to present alternatives and every presentation will necessarily emphasize some factors over others (if only by presenting some factors or options first and others later or last), the lawyer will inevitably be involved in and influence the choices made by the client.

Of course, we have focused in this discussion on the moral implications of framing vis-a-vis the client's well-being. There are additional moral dimensions to the framing issues in Dothard and Johnson Controls. For example, insofar as the lawyers in those cases framed the issues in such a way as to leave the background conditions unchallenged, they failed to seize available opportunities to address situations that posed harm to others-to inmates and guards in Dothard, to male workers in Johnson Controls. ${ }^{77}$ The standard response is that the lawyer's job is to represent the client's interests, not those of third parties. ${ }^{78}$ However, that response merely reframes the moral question without answering it.

The lawyer, then, is necessarily implicated in the task of framing the issue, a role lawyers tend to be less anxious to deny when they have been successful in a case (though, as we have seen, evaluating success can be difficult). Although the framing of the issue seems but a technical legal skill, part of the "craft" of lawyering, it can be understood to have a moral dimension, for every framing highlights some facts as problems, but treats

75. Anthony V. Alfieri, Reconstmuctive Poverty Law Practice: Leaming Lessons of Client Narrative, 100 YALE L.J. 2107 (1991).

76. See, e.g., William H. Simon, Lawyer Advice and Client Autonomy: Mrs. Jones's Case, 50 MD. L. REv. 213 (1991).

77. See KenNEDY, supra note 72, at 248 ("We assert that something that is background for others is causally important in the hope that if we are right, and we can make people see it, we will make it plausible that there are more ways to change the status quo than previously appeared.").

78. See infra note 101 (quoting Lord Brougham's famous speech on the lawyer's duty of loyalty). 
others-even quite troubling facts, such as the inhumane conditions of the prisons in Dothard - as givens. Seen this way, moral decisions are woven into lawyers' everyday technical work.

\section{B. Applying the Law}

In law school, students learn to apply the law to facts, and practicing lawyers use this skill every day. A client seeks a divorce and wants to know whether she will be able to keep a country home she inherited from her parents. In order to answer this question, the lawyer will consult the relevant equitable division statute to see what it says about property acquired by gift or inheritance. If it is ambiguous, the lawyer might also examine the case law interpreting the statute. The lawyer must take the language of the statute and the holdings of the cases and apply them to the facts as the client has explained them. If, for example, the statute exempts from equitable division property inherited before the date of the marriage, and the client's parents died before she married, the lawyer will likely advise her that the law will permit her to keep the country home.

As with issue framing, sometimes the application of law to facts is not straightforward, and it is possible to generate divergent arguments about what the law does and does not permit. Imagine, for example, that the equitable division statute exempts property received by one spouse through inheritance, but includes property received by gift to both spouses. Assume also that, subsequent to her marriage, the client's parents devised the house solely to her, but only after the client, her husband, and their children had spent multiple summers with the client's parents in the home, and after discussions indicating the parents wanted the country house to go to "them" (the client and her husband) because they obviously loved the house so much. Here, a literal interpretation of the statute would support the conclusion that the wife will be able to keep the house after divorce, but most lawyers will see a possible argument that, notwithstanding the form of the devise, the house was meant as a gift to both spouses and should be subject to equitable division.

Ambiguities such as these are quite common in legal practice. Indeed, they are what keeps legal practice interesting, for they call upon the lawyer's skill in constructing arguments-marshaling facts, reading statutes and case holdings carefully, understanding the intent of the statute and the rationales of the relevant cases, etc. Lawyers understand that multiple arguments are possible on both sides and, as with issue framing, they understand an important element of their craft to be their sense, based 
again on intuition and experience, of which arguments will be most effective. That is, they experience themselves as having to make choices about which arguments to advance and how to advance those arguments. But, as with issue-framing, lawyers do not tend to understand these choices as moral in nature.

Imagine a lawyer in Palisades Park, New Jersey, whose client asks him whether he can build a motel at a certain location within the town. The year is 1955 . The lawyer examines the local zoning map and determines that the land in question is located in an area zoned "District A." District A is generally restricted to one and two family dwellings and apartment houses. While the ordinance is silent as to hotels and motels, "boarding and rooming houses" are expressly permitted in the A District. The ordinance defines a boarding house as "any dwelling in which more than six persons not related to the owner or occupant by blood or marriage are lodged and boarded for compensation." A rooming house is defined as "any dwelling wherein furnished rooms are rented to more than six persons for compensation, provided, however, the lodging of relatives, by blood or marriage, of the owner or occupant of such dwelling shall not come within these terms."

Should the lawyer advise the client that the zoning ordinance permits the motel to be built? Unless a motel is not a "dwelling," it would seem to fit easily within the statutory definition of boarding and rooming houses, and since those are permitted uses, it would seem the motel is permitted as well. Let us hope that the attorney did not state this conclusion too definitively, for in the case from which these facts are drawn, Pierro $v$. Baxendale, ${ }^{79}$ the court found:

[M]otels may without difficulty be differentiated from boarding and rooming houses. Motels are business institutions which cater to members of the general public and by and large obligated to serve them indiscriminately. As such business institutions they possess, in substantial degree, the attributes which have led to the exclusion of businesses generally from residential zones. On the other hand, boarding and rooming houses may select guests with care and are admittedly "less public in character." They are located in buildings which have the outward appearances of private dwelling houses and their commercial features and incidents are insignificant when compared to those of motels. ${ }^{80}$

79. 118 A.2d 401 (N.J. 1955).

80. Id. at 405 (emphasis added) (citation omitted). 
"What?," you might think. "The statute doesn't say anything about 'business institutions,' and anyway, it defines boarding and rooming houses in terms of lodging 'for compensation,' so why is it a problem that a motel is a business? And where does the statute say anything about the buildings' 'outward appearance' or 'public character'?"

On second thought, however, it is not difficult to imagine the kind of argument that produced the court's holding. Statutes have not only language, but purposes as well, and it is clear that the lawyer for Palisades Park argued that, notwithstanding the ordinance's literal terms, its intent was not to allow the building of motels within the municipality. He must have been pretty persuasive on this score, as the court held that, "as we view the terms of the ... ordinance the borough contemplated the exclusion of hotels, motels and similar businesses from the residential zones without, nevertheless, curbing the right of dwelling house owners or occupants to use their premises for boarding and rooming house purposes." 81

How could the township attorney persuade the court to reach this conclusion given the clarity of the statute? The opinion's final paragraphs may provide at least a partial answer to this question. The court there meditated on whether the municipality's exclusion of motels was a proper exercise of its zoning powers:

[W] e need but look about us at our many blighted urban and even suburban areas to observe the combined effects of lack of municipal vision and restrictive judicial pronouncements. We are satisfied that at long last conscientious municipal officials have been sufficiently empowered to adopt reasonable zoning measures designed towards preserving the wholesome and attractive characteristics of their communities and the values of taxpayers' properties....

The environmental characteristics of many of our beautiful residential communities are such that the establishment and operation of motels therein would be highly incongruous and would seriously impair existing property values. We know of no sound reason why such communi-

81. Id. at 403 (emphasis added). The court's conclusion that the statute implicitly excluded motels is all the more surprising in light of the fact that within a week of plaintiff's application for a building permit, the borough amended its zoning ordinance to expressly prohibit "motels, motor courts, motor lodges, motor hotels, tourist camps, tourist courts, and structures of a similar character intended for a similar use." Id. at 402 . Under the court's interpretation of the original ordinance, the amendment had no legal effect. 
ties may not, as part of their comprehensive zoning, reasonably exclude such enterprises. ${ }^{82}$

Here, we seem to have reached something different from technical argumentation about statutory language and purpose. We confront the value-laden question of the kind of community Palisades Park is going to be-a community that risks the presence of "blighting" motels, or a community that stoutly preserves high property values and the virtues of suburban life. With the clear hindsight of forty years and the infamous Mt. Laure ${ }^{83}$ exclusionary zoning decisions, the suburban values being invoked seem somewhat less wholesome than the court suggests. In terms of persuasion, however, it is clear that the invocation of property values and motels' potential to destabilize them was extremely powerful. Against the destruction of Palisades Park's beauty, what could the plaintiff possibly offer? A few measly dollars of extra tax revenue?

Many lawyers would characterize the final paragraphs of the Pierro opinion as a classic "policy" argument. As noted earlier, ${ }^{84}$ policy arguments could be understood to be fundamentally moral arguments, i.e., arguments about important values and desirable consequences. But when used in legal argumentation, policy becomes Janus-faced. For the lawyer seeking to persuade the court, policy is one more strategic tool to advance the client's interests. Indeed, American legal education teaches that policies, such as deterrence, cost-spreading, or intent effectuation underlie large bodies of doctrine, and students learn to make policy arguments along with more technical doctrinal arguments throughout their law school careers. On the other hand, for the judge, who must choose among conflicting understandings of the law, policies can help bring to light what conflicting values are at stake. Thus, for the judge, policy has a distinct moral significance. In this light, the court's reliance on the policy behind the zoning statute is hardly shocking. ${ }^{85}$

82. Id. at 408 .

83. Southern Burlington County NAACP v. Township of Mount Laurel, 336 A.2d 713 (N.J. 1975), cert. denied 423 U.S. 808 (1975); Hills Dev. Co. v. Township of Bernards, 510 A.2d 621 (N.J. 1986); Southern Burlington County NAACP v. Township of Mount Laurel, 456 A.2d 390 (N.J. 1983). III.B.

84. See supra text accompanying notes 18-20. See also discussion infra Part

85. But see KENNEDY, supra note 72 , at 110 ("Policy arguers present it as different from pure politics, or ideology, because it appeals to universal rather than particular interests . . . . There is nonetheless a serious problem . . . . Although policy argument formally excludes ideology, it is 'soft' and so operates always under the suspicion of permitting ideology to enter sub rosa."). As we note in our Conclusion, our use of the terms "morality" and "moral" are delib- 
Let us think a little more about the particular policy invoked in this case. First, it is not entirely obvious, given the language of the statute, that its policy is to exclude all business enterprises from residential zones, preserve property values, or prevent blight. Could not the policy of the statute plausibly be argued to be an expansion of owners' freedom, even within residential zones, to use their property for profit, so long as those profits come from lodging people?

Second, even assuming the court correctly characterized the statute's policy, are not other important policies at issue in the case? For example, as read by the court, the zoning ordinance does not actually provide notice of what uses are permitted or forbidden within District A zones. Notice and the predictability that follows from it are also important policies within the law. Why are these policies not even mentioned?

Finally, the opinion's closing paragraphs invoke the desirability of community self-determination and responsible, responsive government. These are value judgments. The values in question are purchased at a price. If the motel is not permitted in Palisades Park, those who might have stopped there will go instead to the neighboring town of Fort Lee, where motels are permitted. ${ }^{86}$ Presumably the residents of Fort Lee, having lacked the foresight to prohibit motels, deserve to face the risk of blight and low property values Palisades Park has avoided. This is also a value judgment-a quite controversial judgment about the acceptability of externalizing certain social costs onto other communities. Calling the values in question "policies" dresses them in comforting pseudo-scientific garb, but the cloak cannot totally hide the lurking moral questions about how local democracies ought to behave when faced with what are perceived as threats to those "inside" the community's walls.

Our point is that garden variety standard legal techniques for applying law to facts, or for arguing about the application of law to facts, encode moral positions that tend not to be recognized as such. "Plain meaning" arguments encode positions about the importance of notice, while "legislative intent" arguments encode positions about the importance, in a democracy, of giving effect to the choices of elected representatives. "Policy" arguments encode moral decisions about how social relations ought to be structured.

erately expansive. We do not contest Kennedy's characterization of such value judgments as political or ideological in nature. Our point is that they are also moral.

86. 118 A.2d at 402 . 
Lawyers make these arguments all the time, thinking of them as purely strategic. But there is another way of thinking about what the lawyer does when making policy arguments. She seeks to persuade the court to choose one set of values over another, to persuade the court that the world should be this way, rather than that way. That can be understood straightforwardly as moral argumentation. If the lawyer "wins," she has not merely achieved the client's goals, but since legal decisions have consequences, she has also helped shape the world for the immediate and third parties, who will be affected by the new decisional law. Looking at the matter this way, we might think that the lawyer's arguments about how to apply law to facts carry with them moral accountability.

\section{Some Observations about the "Field" of Professional Responsibility}

Conventional wisdom has it that professional responsibility is a relatively new field of law. The Watergate scandal and the subsequent low esteem in which the public held lawyers, among other factors, pushed the subject into far greater prominence than it had previously held in law schools. The development of newly-required courses in the subject created a cadre of academics who devoted their principal efforts to professional responsibility issues and gave such issues scholarly respectability.

The same decades that saw an explosion of attention to professional responsibility have seen widespread interest in the potential connections between law and other disciplines. "Law and society", 87 "law and literature", 88 and especially "law and economics" have all become increasingly influential. ${ }^{89}$

Yet, despite this relatively new academic interest in professional responsibility and despite the current academic fashion of breaking down interdisciplinary boundaries, the dominant understanding of the field of professional responsibility in legal education has a surprisingly antique feel. Professional responsibility could easily be seen and constructed as another blended

87. For an overview of the law and society movement, see Marc Galanter \& Mark Alan Edwards, Introduction: The Path of the Law Ands, 1997 Wis. L. Rev. 375; Lawrence M. Friedman, The Law and Society Movement, 38 STAN. L. Rev. 763 (1986).

88. For an overview of the law and literature movement, see Jane B. Baron, supra note 8.

89. The influence of law and economics is conceded even by its critics. See Robin West, CARING For Justice 180 (1997) (conceding that law and literature, for example, is a "marginal movement" as compared with law and economics). 
field-"law and ethics," perhaps, or more broadly, "law and philosophy." Yet, as we have described in the preceding sections, this is precisely not how the field has been defined. If anything, the field as it appears in the law school curriculum seems opposed to definition in terms other than the regulatory provisions that make up the "law of lawyering." Constructed largely along Langdellian lines, professional responsibility is widely understood to comprise distinctly legal materials, to address distinctly legal issues, and to coexist only contingently with other disciplines, including ethics.

In this Part, we consider the appeal of this construction of the field. In the first section we explore its connection to the dominant conception of the lawyer's role as that of neutral partisan and to the justification of that role in terms of the adversary system. We argue that the dominant conception demands a substantial amount of ethical freedom for the practicing lawyer to offer her clients zealous advocacy, even if doing so results in acts of injustice, and that the construction of professional responsibility as a barren field of legal doctrine seems to promise that freedom. But as many leading professional responsibility scholars have shown, this allure rests on shifting sands. Neither the model of neutral partisanship nor the moral justification of the adversary system nor the requirements of professional responsibility doctrine is sufficiently stable and coherent to provide the required ethical freedom. We offer a summary of those demonstrations of the field's indeterminacy and wonder about the fact that they have largely been ignored.

In the second section, we suggest that the construction of professional responsibility as a field of law, separate-even autonomous-with respect to other fields, such as ethics, reflects the enormous and enduring power of Langdell's vision of law generally as a discrete, self-contained discipline. So tenacious is this vision that even the most trenchant critics of the dominant law school construction of professional responsibility, scholars, such as David Luban and William Simon, cannot escape the hold of Langdellianism.

And so at the end of this Part, we return to the very notion of a legal "field." To many, professional responsibility cannot be taken seriously as a field of law, worthy of study and consideration by law students and lawyers, unless it is constituted by and contains precepts that are distinctly legal. While not everyone would define "distinctly legal" the same way, it is clear that the more a group of principles-in this case, the principles of professional responsibility-takes the familiar form of the existing law of torts, contracts, and so forth, the more recognizable it will be 
as "law." But the pressure to make professional responsibility look like other areas already recognized as law has the quality of a self-fulfilling prophecy. Only because we have already decided that a legal field must be constituted by legal rules do we demand that rules be the focus of our new legal field. The question is why there is so deep and widespread an investment in constructing legal fields around doctrine, and distinguishing them so dramatically from other, clearly related fields such as "ethics" or "philosophy." 90 The field of professional responsibility retains an oldfashioned, Langdellian autonomy, an autonomy perhaps less complete than Langdell himself might accept, ${ }^{91}$ but still sufficiently pronounced to surprise those who are confident that American law has somehow passed through or transcended its need to be an autonomous discipline. ${ }^{92}$

\section{A. The Allure of the Law School Construction of Professional Responsibility}

\section{Promises of the Law School Construction}

In this section, we consider why the Langdellian construction of law and professional responsibility is dominant in the law school curriculum. What is its allure?

Perhaps most importantly, the construction of professional ethical issues as potholes, which the attentive lawyer can anticipate and avoid or safely negotiate, resonates with the standard conception of the lawyer's role as the neutral partisan, who zealously advocates in pursuit of the client's goals within the bounds of the law. Zealous advocacy is a commodity for which there is a great demand, ${ }^{93}$ and to provide that commodity, the practitioner requires considerable freedom from ethical constraint in two senses. First, if the lawyer's role is to advocate zealously the client's goals, the lawyer needs to be free of constant fear that her

90. For general observations about this phenomenon, see Jane B. Baron, Interdisciplinary Legal Scholarship as Guilty Pleasure: The Case of Law and Literature, in LAW AND Literature 21 (Michael D.A. Freeman \& Andrew D.E. Lewis eds., 1999).

91. On Langdell's views, see Grey, Modern American Legal Thought, supra note 3; Grey, Langdell's Orthodoxy, supra note 3.

92. See, e.g., Richard Posner, The Decline of Law as an Autonomous Discipline: 1962-1987, 100 HaRv. L. REv. 761 (1987).

93. There may also be great demand for service to the interests of the community at large. Robert Post has suggested that because society wants lawyers to "uphold the right and denounce the wrong" and also to serve individual interests against those of the larger community, lawyers are caught in a contradiction. Robert C. Post, On the Popular Image of the Lawyer: Reflections in a Dark Glass, 75 CAL. L. Rev. 379, 380 (1987). 
tactics and strategies on behalf of the client will risk professional or legal sanctions. Second, as a matter of self-respect, most lawyers will want to believe that their conduct is ethically justifiable in the larger sense of (nonlegal) ethical considerations, and this requires freedom from those ordinary ethical constraints that might clash with zealous advocacy. The particular construction of law and professional responsibility typically found in the law school curriculum seems to promise this ethical freedom to a substantial degree.

\section{a. Freedom from Sanction}

By the time the law student finally takes the course in Professional Responsibility, she has likely encountered many images of the lawyer: the advocate, the counselor, the "statesman," 94 the "people's lawyer" dedicated to justice. ${ }^{95}$ But surely the dominant image is the culture's standard conception of the lawyer: the neutral partisan. Part of that conception is an attitude that treats legal doctrine as material to be mastered and manipulated for strategic maneuvering in the service of the client's interests.

And so when the law student takes the course in Professional Responsibility and encounters yet another body of legal doctrine, she knows exactly what skills are needed to engage it successfully. There is no obvious reason why the previously learned skills of case analysis, synthesis, interpretation, fact analysis, issue framing, and logical application of law to facts should not permit mastery of the law of professional responsibility. And the law student knows exactly how decisions are to be made when the inevitable "play in the joints" is encountered; they are to be made strategically to serve the client's interests.

Here, however, the interests to be pursued strategically are not just the client's, but also the lawyer's own. In the standard conception, both the client and the lawyer (and hence, the law student) have an interest in reducing the size of the ethical potholes through the interpretation and application of professional responsibility doctrine. We see that the lawyer/law student has such an interest not just by inferring a self-defensive urge to minimize the degree of disciplinary peril attending the lawyer's work. More generally, the ideology of neutral partisanship generates strong incentives to shrink the potholes. For, if the lawyer's job is to pursue the client's self-defined interests,

94. See Anthony T. Kronman, The Lost Lamyer: Failing Ideals of THE Legal Profession 11-14 (1993).

95. See Louis D. BrandeIs, The Opportunity in Law, in Business-ProfesSION 321 (1914). 
then navigating ethical problems impedes and slows down that pursuit, and constant fear of sanctions can chill the lawyer's zeal.

The entrenched reaction of law students to approach the law of professional responsibility strategically like any other body of law is encouraged by the very form of that law. The centerpiece of the doctrine in this field is a code of ethical rules, typically based on the A.B.A.'s Model Rules of Professional Conduct, which possesses several features that affirmatively reinforce the student's inclination to think about ethical problems as potholes and approach the rules governing those problems strategically.

First, the immediate source of the ethical rules is external to the individual whose conduct is governed. Like other bodies of law, they are promulgated by an authoritative rule-maker, typically, the supreme court of the state. When ethical rules are promulgated by an external authority, does one follow the rules because it is the right thing to do or because obedience to an external authority is required? If the rule-maker is presumed to be good, as when the rule-maker is a god, these two motivations merge. But the government is not a deity; consequently, the identity of the right and the required is hardly self-evident. When the professional ethical rules are disengaged from any necessary connection to ordinary morality, the issue becomes one of compliance. In the universe governed by such rules, the central ethical question is not, "What should I do?" but, "Is this conduct allowed?" And, freed from any necessary connection to ordinary morality, the lawyer/law student is at liberty to approach this question strategically - to minimize the ethical potholes lying in the way of zealous advocacy.

Second, the meaning of the ethical rules is variable. This is so because disparate principles can inform the interpretation of any rule. As with any legislation, one can give an ethical rule its plain meaning, the meaning intended by its author, or the meaning that carries out its purpose. And, as with other rules that the student has practiced with over the years, the selection of an interpretive approach can be further complicated by irresolvable disagreements over the plain meaning, the authorial intent, or the rule's purpose. To the extent that the meanings generated by these necessary choices are inconsistent, the ability of ethical rules to guide behavior is compromised. As with other rules encountered by the student, the variable meaning of the rules of ethics openly invites strategic interpretation to narrowly constrict their scope. 
Third, ethical rules are both under- and over-inclusive. ${ }^{96}$ As with variability of meaning, this feature stems from a characteristic of all rules, namely that the language of rules is general, while the situations to which they apply are particular. Thus, a rule requiring a child to be in bed by nine o'clock may on its face improperly prohibit her staying up to watch an important educational program that ends at nine-thirty, and improperly permit her to stay up until nine when she is sick and ought to go to bed early. ${ }^{97}$ Since no amount of specification will cure this problem, the implications for an ethical regime are clear: insofar as ethics are defined by rules, some right conduct will be prohibited and some wrong conduct will be allowed. Again, this feature invites strategic interpretation. Students are drilled in the skills of exploiting the under- and over-inclusiveness of rules to the client's advantage by shifting back and forth between interpretive modes (plain meaning, legislative intent, purpose analysis, etc.) in order to shape the reach of the rules to permit the desired conduct. It is a relatively straightforward task to employ those skills to the student-lawyer's advantage in dealing with the A.B.A. Model Rules.

Fourth, ethical rules, like all rules (even the most crystalline), have qualities of vagueness and open-texture. ${ }^{98}$ A rule is vague insofar as the boundary between which situations are addressed by the rule and which are not is indistinct. In such a case, it cannot be determined without modification of the rule (by formally amending the rule or through interpretation) whether a situation falling at the boundary is included or excluded. A rule is open-textured insofar as all future situations to which the rule might be applied cannot be anticipated. Again, no amount of specification will immunize a rule from either vagueness or openness of texture. For ethical rules, this means that we can expect to encounter ethical problems that are underdetermined by application of the rules. As with the second and third features discussed above, the student arrives in the professional responsibility course well practiced in exploiting the vagueness and open texture of rules.

96. See Frederick Schauer, Playing by the Rules 31-34 (1991).

97. For another examination of legal reasoning and parents' bedtime rules, this time from the perspective of the child, see Jeremy Paul, A Bedtime Story, 74 VA. L. REv. 915 (1988).

98. The idea that language has an uneliminable "open texture" is generally attributed to Friedrich Waismann. See Friedrich Waismann, Verifiability, in Logic and Language: First Series 117 passim (Antony Flew ed., 1951). For its application to legal rules, see H.L.A. HART, THE ConcePt OF LAw 120-32 (1961); SCHAUER, supra note 96, at 34-37. 
In sum, these four characteristics of a code of professional ethics encourage strategic approaches. First-year instruction teaches students that obedience to externally promulgated rules turns on their meaning, which turns on interpretation and application. Students are further taught that interpretation and application are flexible precisely because rules are variable in meaning, over- and under-inclusive, vague, and open-textured. The interpretive skill lawyers apply to provisions of a commercial code to argue that the statute either allows, requires, or forbids the conduct in question can be readily employed to construe the provisions of the Model Rules of Professional Conduct. The self-interest and internalized ideology of student-lawyers lies in advocating for maximum autonomy in their legal practice, which means arguing for interpretations of the rules that shrink the ethical potholes to the greatest degree.

\section{b. Freedom from Moral Accountability}

The standard conception of the lawyer as a neutral partisan, who uses his knowledge and skill to zealously advance the goals of the client, seems to countenance injustices. That is, the conception seems to require lawyers to do things that would, by ordinary ethical standards, be considered immoral. ${ }^{99}$ Consider the lawyer who successfully raises a statute of limitations defense on behalf of his client to defeat the collection of a just debt. ${ }^{100}$ Consider the lawyer who successfully impeaches a truthful witness to secure the acquittal of a dangerous criminal. The public recoils at the image of the lawyer as a hired gun, inflicting injustices on individuals and society as a whole to carry out the wishes of the client. $^{101}$

99. See generally Arthur Isak Applbaum, Ethics for AdVersaries: The Morality of Roles in Public and Professional Life (1999); see also Postema, supra note 21.

100. See Resolution 12 in David Hoffman, Resolutions of Professional Deportment (1836), quoted in LuBAN, supra note 21, at 10 ("I will never plead the Statute of Limitations, when based on the mere efflux of time, for if my client is conscious he owes the debt; and has no other defence than the legal bar, he shall never make me a partner in his knavery.").

101. The famous summation of this position is Lord Brougham's speech before the House of Lords during the trial of Queen Caroline. "An advocate," he insisted, "by the sacred duty which he owes his client, knows in the discharge of that office but one person in the world, that client and none other." The lawyer must be willing to risk "all hazards and costs, to all others, and among others to himself ...." Indeed, the lawyer must even be willing to risk "involv[ing] his country in confusion for his client's protection." Quoted in Deborah Rhode, An Exchange on Adversarial Ethics: Text, Subtext, and Context, $41 \mathrm{~J}$. Legal Educ. 29, 29 (1991). See also Leonard E. Gross, The Public Hates Lawyers: Why Should We Care?, 29 Seton Hall L. Rev. 1405 (1999). Robert Post has 
Since we can assume that most people, including most lawyers, wish to think of themselves as basically moral, we need to see how the lawyer from her first days as a law student constructs a reliable moral justification for the standard conception. That justification is found in the vision of law and legal practice consistently and relentlessly presented and reinforced throughout law school, beginning in the first-year curriculum. For in that vision, dominated by the conception of the lawyer as a neutral partisan, the dominant ethical value is loyalty to the client, ${ }^{102}$ and the justification for the priority of that value is the essentiality of the advocate's role in the adversary system, which is itself justified in consequentialist terms. ${ }^{103}$ That is, the adversary system is presented (along with all the essential roles within the system) as producing a net benefit to society, even if it also necessarily produces local injustices along the way.

Moreover, even with regard to those local injustices, accountability is displaced. It is the client who chooses the goals; it is the jury who decides the facts; it is the judge who decides the law. The lawyer's role is instrumental: to assist the client in achieving her goals and to show how the facts and the law can be construed to favor those goals. The lawyers who represented the Klan's desire to march in Skokie were not vouching for the virtue of the march (the Klan had that responsibility), nor did they have the power to decide that the march was proper (the judge had that responsibility). ${ }^{104}$ Similarly, the criminal defense lawyer

noted that the public's disenchantment is profoundly ambivalent. Analyzing a 1986 survey of public attitudes toward lawyers, What America Really Thinks About Lauyers, NAT'L L.J., Aug. 18, 1986, at S-3, Post observes that while the public objects to the fact that lawyers "manipulate the legal system without any concern for right or wrong" and "file too many unnecessary lawsuits," the public also approves of the fact that lawyers' "first priority is to their clients" and that they "know how to cut through bureaucratic red tape." Post, supra note 93, at 380 (quoting $i d$.).

102. See Robert W. Gordon, The Ethical World of Large-Firm Litigators: Preliminary Observations, 67 FordHAM L. REv. 709, 737 (1998); W. Bradley Wendel, Public Values and Professional Responsibility, 75 NOTRE DAME L. Rev. 1, 47-62 (1999).

103. See Simon, supra note 60, at 53; David Luban, The Adversary System Excuse, in The Good LaWyer: LaWyers' Roles and LaWyers' Ethics 83, 93-104 (David Luban ed., 1983) [hereinafter Good LAWYER]. Nonconsequentialist justifications have been offered. See, e.g., id. at 113-117 ("pragmatic" justification); Charles Fried, The Lawyer as Friend: The Moral Foundations of the Lawyer-Client Relationship, 85 YALE L. J.1060 (1976) (lawyer is a "special purpose friend"). However important such nonconsequentialist arguments have been within the academy, the public at large and the professional disciplinary institutions largely rely on the consequentialist rationales.

104. Cf. Wendel, supra note 102, at 55 ("The Jewish lawyer who argued in favor of the Nazis' right to march in Skokie, Illinois was not motivated to 
who allows her client to testify, knowing that she intends to commit perjury, is not accountable for the perjury; that is the client's decision and responsibility.

Hence, the freedom from moral accountability demanded by the conception of the lawyer's role as that of neutral partisan is provided by a construction of the legal system in which the lawyer plays a specific and essential role. On the one hand, the role is justified (including any bad consequences of carrying out the role) because the system as a whole is justified. On the other hand, other actors assigned other roles are delegated responsibility for the ethical dimensions of the representation. ${ }^{105}$

$$
\text { * ** }
$$

The foregoing discussion has argued that the typical law school construction of law and professional responsibility has a strong appeal because it powerfully complements and supports the standard conception of the lawyer's role as neutral partisan by substantially clearing the lawyer's activity of moral constraints. However, other dimensions of its appeal should not be shortchanged.

The first year of law school demands an intellectual rigor that is exhilarating for many students and which, along with the arcane language in which law is presented, lends an air of elite dignity and power that coincides with some of the important

increase the Nazis' freedom to terrorize his people; instead, he located the value of his efforts in the goal of vindicating important First Amendment values."). See generally Aryeh Neier, Defending My Enemy: American Nazis, The SKokie Case, aNd THE Risks of Freedom (1979).

105. Actually, even the judge largely escapes moral accountability in the law school's account of law. The judicial role is itself constructed in terms of craft. The judge's job is to decide cases in terms of precedent, i.e., in a manner consistent with past decisions. The notion of consistency that is reinforced in the first-year study of law is a thin one, largely devoid of moral significance. By contrast, when Ronald Dworkin argued that consistency should be understood in rich terms that include background moral and political values, RONALD Dworkin, Hard Cases, in Taking Rights Seriously, ch. 4 (1977), he was understood by many to be theorizing in the natural law tradition. See, e.g., Thomas Morawitz, Law as Experience: Theory and the Internal Aspect of Law, 52 S.M.U.L. Rev. 27, 47 n.74 (1999); Richard A. Posner, Dworkin, Polemics, and the Clinton Impeachment Controversy, 94 Nw. U.L. REv. 1023, 1035 (2000). For Dworkin's early views on this reading of his work, see Ronald Dworkin, "Natural" Law Revisited, 34 U. Fla. L. Rev. 165 (1982). See also Anthony J. Sebok, Legal PosiTIVISM IN AMERICAN JURISPRUDENCE 239-40 (1998). Accordingly, a common view of law students is to divide cases in which the judge is seen to "follow the law," from those in which the judges' decisions are deemed "result oriented" - the latter being decisions that clearly involve choices among competing values. 
motivations for attending law school. ${ }^{106}$ Once this understanding of intellectual rigor is internalized, the construction of professional responsibility as a field of law follows. That is, students come to expect that a serious topic of study will look like the firstyear courses. Accordingly, a Professional Responsibility course that looks different-in which, for instance, the teacher focuses on problems and employs a discursive pedagogy-will likely be perceived as "soft," not rigorous, not to be taken seriously. ${ }^{107}$

In addition, the construction of law and legal ethics in terms of authoritative sets of rules and attendant doctrines appeals to the predominant ethical orientation of beginning law students. The available research indicates that as compared with the general population, incoming law students disproportionately view ethics in terms of an objective set of social rules and norms which should be followed for the sake of order and stability more than for their tendency to achieve specific justice in each individual situation. ${ }^{108}$ Moreover, for the minority of first-year students who arrive with a more contextualized or relational or deontological ethical orientation, the research suggests that their consistent and relentless confrontation with the dominant construction reshapes their ethical views toward the rules-and-order model. ${ }^{109}$

\section{The Indeterminacy Problem}

We can summarize the discussion thus far. In light of the way professional responsibility is placed and taught within the law school curriculum, many students and practicing lawyers come to think of professional responsibility issues in some variant of the following: legal "ethics" involve a small group of problems primarily having to do with issues of confidentiality, conflicts and the like. In the relatively rare instances when such problems arise, the lawyer should consult the A.B.A. Model Rules or other analogous regulations in force in his or her jurisdiction. As the Rules confirm, the lawyer's role is best understood as that of a neutral partisan; the client determines the ends of the representation, and the lawyer's job is to zealously pursue those ends (within the bounds of the law, of course). Sometimes, the lawyer in her role as neutral partisan will feel obligated to perform an

106. See Susan Daicoff, Lawyer, Know Thyself: A Review of Empirical Research on Attorney Attributes Bearing on Professionalism, 46 AM. U. L. REv. 1337, 1356-62 (1997).

107. See Ronald M. Pipkin, Law School Instruction in Professional Responsibility: A Curricular Paradox, 1979 AM. B. Found. REs. J. 247.

108. See Daicoff, supra note 106, at 1395-1403.

109. See, e.g., Sandra Janoff, The Influence of Legal Education on Moral Reasoning, 76 MINN. L. REv. 193 (1991). 
act she feels is unjust, such as raising a statute of limitations claim to defeat a just debt, or withholding information that, if known to the other side, would affect ongoing negotiations, or impeaching a witness the cross-examining lawyer knows to be telling the truth. While acts such as these might seem deceptive or wrongful outside the legal context, they are justified within the legal context, where the adversary system governs. The norms of the adversary system ensure that any "wrongs" on one side will be righted or balanced by the equally zealous efforts of the attorney on the other side. Out of the clash of the two sides' strongly represented interests, truth and/or justice will emerge.

As we suggest, this understanding of professional responsibility issues has a powerful appeal for law students and practitioners. The malleability of professional responsibility doctrine holds out the promise that lawyers can provide their clients with zealous advocacy without fear of sanctions, even if their zealous advocacy generates local injustices toward opposing parties, third parties, or the general public. In addition, neutral partisanship and the adversary system rationale hold out the promise of moral justification for these local injustices.

This view of lawyers' ethics is often called the dominant view. ${ }^{10}$ What is interesting about its dominance is that each and every part of it has been thoroughly and persuasively shown to be internally contradictory and incoherent. Its robust survival within legal education, as well as its largely uncritical acceptance by law students and practicing lawyers, is truly astounding.

\section{a. The Indeterminacy of Professional Responsibility Doctrine}

Once professional responsibility is constructed as a field of law, i.e., as a series of regulatory provisions with supporting policies, the field must struggle with all the usual problems that make it difficult to apply rules in a straightforward manner. As we have described, within the curriculum the particular constellation of rules governing professional responsibility become but a new sphere on which to practice harmonizing, distinguishing, interpreting, analogizing, and so forth. Paradoxically, even as the casebooks construct the field as a field of law, they demonstrate how few answers the rules in the field actually provide. For instance, a case interpreting a rule one way is typically followed by a case interpreting the rule very differently in order to demonstrate the pull of the competing values animating the rules. Fact pattern after fact pattern is offered to show how various duties of confidentiality potentially conflict with duties of candor to the

110. See, e.g., Simon, supra note 60 , at 7. 
tribunal or how duties of loyalty to client potentially conflict with duties to serve the public interest.

Thus, if professional responsibility is constructed to look just like a field of law, then it will behave just like a field of law. The same techniques that allow the self-serving lawyer to contract the scope of ethical potholes will allow the lawyer's critic to expand those potholes. The variability, over- and under-inclusiveness, vagueness, and open texture that characterize the Model Rules work both ways. These features allow an advocate to contract the scope of the professional responsibility law to maximize the freedom for zealous advocacy, but they also permit the critic to expand the scope of the law to limit that freedom. Monroe Freedman, appealing to professional responsibility doctrine, made powerful arguments for why criminal defense lawyers may ethically put a client on the stand, knowing that the client intends to commit perjury. ${ }^{111}$ In response, then Federal Circuit Judge (later Chief Justice of the United States) Warren Burger, appealing to professional responsibility doctrine, made powerful arguments for why such conduct is unethical. ${ }^{112}$

As leading figures in the field have acknowledged, the Model Rules and their counterparts cannot resolve arguments, such as those between Freedman and Burger because those codes are in some measure the source of the arguments. The codes themselves provide that the lawyer owes duties to self, client, and the public interest without providing any sort of algorithm for resolving conflicts among those potentially conflicting duties. ${ }^{113}$ Even scholars who believe it is important to embody lawyers' ethics in

111. See, e.g., Monroe H. Freedman, Perjury: The Lawyer's Trilemma, 1 LrTIG. 26, 28 (1975); Monroe H. Freedman, Professional Responsibility of the Criminal Defense Lawyer: The Three Hardest Questions, 64 Mich. L. REv. 1469, 1478 (1966); Monroe H. Freedman, Lawyers' Ethics in an Adversary System (1975).

112. Warren E. Burger, Standards of Conduct for Prosecution and Defense Personnel: A Judge's Viewpoint, 5 Ам. CRIM. L. Q. 11, 12-14 (1966). Judge Burger, along with others, instituted unsuccessful disciplinary procedings against Freedman. See also Daniel J. Pope, Of Mice and Men, 66 Def. Couns. J. 569 (1999); Teresa S. Collett, Understanding Freedman's Ethics, 33 ARIz. L. Rev. 455, 464-65 (1991); Bruce M. Landesman, Confidentiality and the Laxyer-Client Relationship, in Good Lawyer, supra note 103, at 191; Donald S. Liskov, Criminal Defendant Perjury: A Lawyer's Choice Between Ethics, the Constitution, and the Truth, 28 NEw ENG.

L. Rev. 881, 905 (1994).

113. See, e.g., Mol.rterno, supra note 4, at 2 :

Lawyers owe duties to clients, the justice system, third parties generally, opposing parties, the society, and the profession. There is a hierarchy among these duties, but all difficult legal ethics questions involve an attempted balancing among these duties. The law governing lawyers, at least the profession's self-regulation/rules, are 
codes of conduct are skeptical of such codes' ability to provide clear answers to even the narrow realm of problems deemed ethical.

\section{b. The Indeterminacy of the Moral Justification of the Adversary System}

It is tempting for the lawyer to try to stabilize the ethical landscape with its small potholes through recourse to the notion that the lawyer's role is essential to the adversary system. If the adversary system is itself morally justified by the net good it produces, then this line of reasoning should suffice to brace the lawyer's narrow construction of ethical constraints against the critic's attempt to expand those constraints. But how stable is the proffered justification? Again, leading scholars in the field have suggested it is not very stable.

The adversary system is principally justified by consequentialist arguments, which claim that the lawyer's rigorous adherence to the role of zealous advocate will, in the long run, produce a net benefit to society in terms of truth, justice, and the protection of rights. ${ }^{114}$ In their most extreme form, they express rule-utilitarian arguments to the effect that rigorous adherence to the role is the best way of achieving truth, justice, or the protection of rights. Thus, the criminal defense lawyer can impeach a witness she knows to be truthful because the conscientious pursuit of her role, along with the conscientious pursuit of the other assigned roles by the other actors in the system, will produce overall good consequences that outweigh this particular injustice. In short, local incidents of injustice are permitted if they are the necessary by-product of the lawyer's role as neutral partisan.

David Luban has argued that the empirical claim that the adversary system is an inherently superior way of maximizing truth, justice, and the protection of rights is both unsubstanti-

essentially an attempted balance among the competing duties in given contexts.

MORGAN \& RotUNDA, supra note 43, at 28:

[I]n an important sense, any rules of professional conduct are an attempt to accommodate at at least five interests. . (1) lawyers as individuals, (2) lawyers in their relationships with each other, (3) lawyers' responsibilities to their clients, (4) lawyers' responsibilities to non-clients with whom the lawyer deals, and (5) institutions of the legal system through which the lawyer works.

Judge Noonan argues that these tensions predate formal codes of professional conduct. NoOnan \& PaINTER, supra note 37, at viii-ix.

114. See supra note 103 , and accompanying text. 
ated and implausible. ${ }^{115}$ Even more fundamentally, consequentialism of this ilk is hardly uncontroversial as a justification. A Kantian, for example, may well believe that it is morally impermissible to deceive the fact-finder by intentionally presenting a truthful witness as a liar-wrong notwithstanding the good consequences that such conduct arguably produces. ${ }^{116}$ Our point, of course, is not to resolve the debate between consequentialists and Kantians. We simply observe that a controversial moral justification for the adversary system (and by extension for the standard conception of the lawyer's role) will not necessarily satisfy critics who do not view ethics from a utilitarian perspective. Furthermore, there is no metatheory to resolve disagreement at this level. Like the abortion debate, the debate over the justification for injustices committed by lawyers within the adversary system has little prospect of achieving anything resembling a consensus. As a result, the lawyer cannot rely on that justification to shore up and stabilize the desired ethical freedom to provide zealous advocacy.

\section{c. The Indeterminacy of the Standard Conception of the Lawyer's Role}

However, even if the utilitarian justification for the adversary system were universally accepted, the standard description of the lawyer's role within that system-that of neutral partisan-itself raises difficult questions. What are the client's interests and goals that are to be zealously advocated? As the earlier discussion of the Dothard and Johnson Controls cases ${ }^{17}$ suggests, identifying the clients' interests in those situations is problematic. What the plaintiffs "won" in Johnson Controls - the right to choose to be exposed to harmful lead-might not at all be in their long-term interest.

But who is to say? In an influential article published in 1978, William Simon demonstrated how quickly the concept of neutral partisanship becomes problematic. ${ }^{118}$ As a partisan, the attorney "should act with commitment and dedication to the interests of the client and with zeal in advocacy upon the client's behalf."119 But does that mean deferring to whatever the client believes to

115. See Luban, supra note 21 , at 93-104. Simon has made similar kinds of arguments. SIMON, supra note 60, at ch. 3.

116. See Roger J. Sullivan, Immanuel Kant's Moral Theory 170-173 (1989).

117. See discussion supra Part II.A.

118. William Simon, The Ideology of Advocacy: Procedural Justice and Professional Ethics, 1978 WIS. L. Rev 29. See also Abel, supra note 1.

119. Model Rules of Professional Conduct Rule 1.3, cmt. (1983). 
be in her interest, or does it mean helping the client to thoughtfully identify her interests? If the latter, what of neutrality? If neutrality means not judging the client's goals, how can the lawyer help the client thoughtfully identify those goals, for such an exploration requires the lawyer to engage in critical judgment. That is, the lawyer must be able to discern strategic, tactical, political, economic, and ethical problems with the client's designs.

And just why must the lawyer's evaluation include ethical problems with the client's objectives? What business is it of the attorney to get the client to focus on the moral implications of the client's goals? Why, for example, should the lawyer care if the client wants to defeat a just debt by raising the statute of limitations? One answer is that if the lawyer's role is to be a partisan in the furtherance of the client's interests, it might be in the client's interests to be a good person. That might be because the client's standing in the community or in her business might be adversely affected by unjust behavior. It might also be in the client's interest to be a good person because the client really wants to be a good person. The lawyer cannot know this without raising the issue, and the issue cannot be raised without exploring the ethical implications of alternative courses of action. And if the client does wish to be a good person and if the client has not clearly thought through the relevant questions of right and wrong, the lawyer who truly wishes to advance the client's goals must provide counseling on these questions. But raising issues of justice and providing counseling on these issues requires dropping all pretence of neutrality, for it demands the exercise of critical ethical judgment. To help the client see what is right and what is wrong, the lawyer has to be able to see and communicate what is right and what is wrong.

In sum, it has been powerfully argued within professional responsibility literature that the kind of exploration necessary to thoughtfully determine the client's interests and goals requires the participants to abandon neutrality and express judgments about the various possibilities. For exactly the reason that it would be contrary to the client's interests for the lawyer to be "neutral" on questions about legal doctrine, it would seem that the lawyer cannot remain neutral on questions about client interests, including the client's interests with regard to ethical conduct. 


\section{d. The Indeterminacy of Act Description}

As Arthur Applbaum has shown, moral nonaccountability is threatened also by the indeterminacy of act description. ${ }^{120}$ The lawyer defends the morality of impeaching a truthful witness by appeal to the lawyer's role: it is morally permissible for a lawyer acting in her role to impeach a truthful witness. Suppose this is so. Nevertheless, the lawyer's critic can redescribe the conduct: a human being is trying to deceive another into thinking that a truthful person is a liar, and it is morally wrong for a human being to engineer such a deception, all the more so when the truthful person is innocent of wrongdoing. Thus, what for nonlawyers would be properly described as deception (morally impermissible) is for lawyers properly described as impeachment (morally permissible). Which description is correct?

The answer might be both. The actor is both a lawyer and a human being, and what is morally permissible for a lawyer to do is impermissible for a human being to do. Yet the lawyer would no doubt respond that there is a lawyer exception to the moral obligation of human beings not to make a truthful person out to be a liar. Thus, the lawyer's description trumps. But who says it does? The lawyer says, and perhaps the profession says, and perhaps the law schools say through their construction of law and legal practice. But why is that binding on the critic? Why should the critic cease to treat the actor as an ordinary human being subject to ordinary moral constraints simply because he and his profession and his school call the actor a lawyer and call his deception impeachment? Clearly the legal profession cannot impose its descriptions on those outside the profession. (Indeed, it arguably cannot impose its descriptions on insiders.) Nor is there any metaprinciple to decide between the competing descriptions.

The lawyer's plea for moral nonaccountability receives explicit support in the Model Rules' insistence that “[a] lawyer's representation of a client . . . does not constitute an endorsement of the client's political, economic, social or moral views or activities." 121 But in the ordinary world, intentionally assisting another to carry out certain objectives frequently is taken to constitute such an endorsement of those objectives. The Model Rules cannot enforce its claim by fiat; it must persuade through moral argument. And if it cannot persuade critics to abandon their alternative descriptions and attendant moral obligations, then so

120. See generally ApplBaum, supra note 99, at ch. 5 (defining, describing, and exploring this problem).

121. Model Rules of Professional Conduct Rule 1.2(b) (1983). 
much the worse for the Model Rules and for the lawyers who appeal to the Model Rules for ethical freedom. The Mafia hitman can insist that contract killings are just fine within the governing ethical principles of the Mafia, but that insistence is impotent to preclude Mafia critics from calling those acts murder and holding the contract killer accountable for murder.

$$
\text { * * * }
$$

These four indeterminacies-the indeterminacy of professional responsibility doctrine, the indeterminacy of the moral justification for the adversary system, the indeterminacy of the standard conception of the lawyer's role, and the indeterminacy of act description-raise serious doubts about the capacity of professional responsibility as constructed in the law school curriculum to supply the ethical freedom lawyers seem to desire. These indeterminacies have not been observed from the margins; arguments about them have been central to the scholarship about professional responsibility. What is puzzling is how the dominant view can retain its hold in the face of such fierce and effective assaults. Hovering above all this is a point we have repeatedly made: it is possible to construct positive law as saturated with moral significance. In such a construction the incentive is not to narrow legal constraints but to expand them. The mystery is why such a construction is so rarely considered.

\section{B. Three (or Four) Constructions of the Field}

It is open to us to understand professional responsibility in different ways, and each understanding has important consequences. Generally speaking, we have maintained that professional responsibility has been constructed as a field of law. But what does that mean? It turns out that it can mean several different things, each of which has implications for our understanding of professional ethics and, ultimately, for our understanding of who we are as lawyers.

One thing it can mean is that professional responsibility consists entirely of legal doctrine-legal rules, legal principles, legal policies-which are applied to various factual situations utilizing the forms of legal reasoning typical of other fields of law. This seems to be the dominant understanding within law school curricula.

Constructed in this way, professional responsibility holds out many promises. It promises self-sufficiency. The lawyer can resolve professional responsibility promises by mastering doctrine; recourse to other disciplines, including ethics, is unnecessary because they are outside the law and largely irrelevant to it. 
So constructed, professional responsibility also promises substantial ethical freedom, protecting the lawyer from sanctions as long as the doctrinal requirements are met and allowing the lawyer to get about the business of zealous representation of the client. The problem with this construction, as we have seen, is that commentator after commentator has demonstrated the indeterminacy of professional responsibility doctrine at all levels, so that it can fulfill neither the promise of self-sufficiency (because mastery of the doctrine does not dictate answers to the important questions of professional ethics) nor the promise of freedom (because the same techniques that expand the lawyer's freedom under the doctrine can be used to contract her freedom).

A second thing that it can mean to construct professional responsibility as a field of law is that professional responsibility is separate from, but supplemented by other disciplines, especially ethics. Put another way, professional responsibility can be understood to be "law and ethics." Our sense from the literature and from conversations with colleagues is that this approach represents a significant minority approach within law school curricula.

Constructed this way, our understanding of professional responsibility doctrine is supplemented and improved by reaching outside the doctrinal boundaries to a different discipline: ethics. But it is important to see that ethics remains outside of law. David Luban has argued, for example, that if "bodies of legal doctrine are organized around principles and counterprinciples, which check each other," as some critical legal scholars have maintained, then lawyers must appeal to moral convictions in choosing among the competing principles. ${ }^{122}$ In this formulation, law and morality remain separate, but connected, domains.

Whether Luban is right-whether the practitioner must or even should appeal to ordinary moral principles in general or in particular cases-remains an open question. More to the point, constructed in this way, it is not a legal question. ${ }^{123}$ The lawyer can reach outside of law and engage in what Luban calls "moral activism," 124 thereby investing her practice with morality. Or the lawyer can reject Luban's counsel, remain within the legal field, seek to comply with the doctrinal requirements of professional

122. David Luban, Reason and Passion in Legal Ethics, 51 STAN. L. Rev. 873, 892 (1999). See also id. at 898 ("[T] he kind of legal analysis Simon favors cannot even begin without a prior moral stance to orient it in an endless field of possibilities.").

123. An interesting question is what kind of question it is. It could be a moral question.

124. LuBAN, supra note 21 , at xii passim. 
responsibility, and ignore the teachings of ordinary ethics. In that sense, one can be a good lawyer, but not necessarily a good person in much the sense that one can be a good plumber (by mastering the technical knowledge and skill), but not necessarily be a good person.

A third thing that constructing professional responsibility as a field of law might mean is that morality is subsumed within law and is, therefore, within the legal field of professional responsibility. William Simon argues that "lawyers should take those actions that, considering the relevant circumstances of the particular case, seem likely to promote justice." ${ }^{25} \mathrm{He}$ defines justice as "legal merit."126 Of course, by "legal merit" Simon does not mean to invoke the narrow regulatory model emphasized by the leading casebook authors. He has a frankly Dworkinian view, which he calls substantivism (in contrast to positivism). Substantivism "interprets specific legal norms as expressions of more general principles that are indissolubly legal and moral." ${ }^{127}$ The substantivist never considers the letter of a law without also considering its spirit or purpose; she never mechanically applies law without considering whether that application is consistent with or promotes the values beneath/behind/animating the law in question.

Notice that Simon's substantivism puts all sorts of moral norms inside the law. Law, Simon argues, incorporates/instantiates ethical debates: "Conflicts the Positivist defines as law-versusmorality take the form, for the Substantivist, of legal norms in tension with each other."128 As one commentator notes:

Simon's proposal ... demands, in essence, a reorientation of the lawyer's professional role toward justice, but does not demand incorporation of extra- or non-legal moral norms. Rather, it demands a reorientation of the lawyer's professional role toward justice so as to be truer to the law itself. . . . It argues, to state the contrast a little differently, for a revitalization or even an enlargement of the lawyer's distinctive professional role so that the lawyer pays his due to the justice already inscribed in our law, rather than a diminution of the lawyer's distinctive professional role to better align it with the dictates (and pieties) of conventional morality. ${ }^{129}$

125. Simon, supra note 60 , at 138 .

126. Id.

127. Id. at 82 .

128. Id. at 99-100.

129. Robin West, The Zealous Advocacy of Justice in a Less than Ideal Legal World, 51 Stan. L. REv. 973, 981 (1999). See also Luban, supra note 122, at 886 
Whether Simon's views are correct is, of course, debatable. ${ }^{130}$ What is more important is the contrast between substantivism and the regulatory model. For Simon, ethics or morality are already inside the legal field, amenable to consideration through application of the techniques of legal reasoning. Legal reasoning necessarily involves moral reasoning, and legal merit necessarily involves justice.

Consequently, questions that involved competing considerations of "law" and "ethics" under the previous two constructions are transformed within the third construction into law/law problems. Simon contrasts these relationships as follows:

First, the law/law characterization suggests that the matter is susceptible to resolution in terms of the analytical methods and sources of legal argument. . . Second, the law/ law characterization suggests that the legal profession or some subgroup of it might have some collective responsibility for its resolution that might call for disciplinary review or simply critical assessment. Moral considerations, on the other hand, are presumed to be a matter for the individual decisionmaker to resolve privately.

The [dominant construction] privileges the law/ moral characterization, and particularly the choices associated with "law." The psychological effect of this privileging is to reinforce lawyers' commitment to conventional responses-client loyalty in all cases where the client's projects are not prohibited by the positive law, obedience to positive law in other cases. Typically, the conventional response is portrayed as the "legal" one, and competing

("Simon claims that if your interpretation of the law makes it morally unacceptable, the fault lies with your interpretation, not with the law.").

130. West asks why Simon does not define the justice lawyers are required to pursue "by reference to the requirements of justice, rather than by reference to law?" Id. at 988. She answers her own question as follows:

[W] e really do not have at our disposal a credible, or even coherent, understanding of the requirements of legal justice, and one reason for that is surely that both the law schools and the bar, at least in this century, have simply neglected the task of producing one ... . We have no sustained body of scholarship that examines the concept. Nor do we teach the concept of justice .... So, when the appealing suggestion that lawyers should pursue justice is put forward, there are seemingly only two alternatives for defining the justice those lawyers ought pursue: Justice might be defined by reference to an idealized conception of extant law, or justice might be defined by the personal predilection of those individuals required to dispense it.

Id. at 988-89. For a strikingly similar observation, see Heidi Li Feldman, Matter of Ethics-Apparently Substantial, Oddly Hollow: The Enigmatic Practice of Justice, 97 Mich. L. REv. 1472, 1478-80 (1999). 
ones as "moral" alternatives. The rhetoric connotes that the "legal" option is objective and integral to the professional role, while the moral option is subjective and peripheral .... The usual effect is to make it psychologically harder for lawyers and law students to argue for the "moral" alternative. The effect of showing that in fact both alternatives could be understood as "legal" is thus sometimes to make the alternative positions seem more grounded and less subjective. ${ }^{131}$

It is important to see, however, that even in Simon's construction, law remains a bounded field. Law incorporates morality, but in so doing, law transforms morality into "the materials of conventional legal analysis." That is, by absorbing morality into the field of law, a part of morality is transformed into law. ${ }^{132}$ Thus, ethical lawyering becomes a matter of attending conscientiously to the conventional concerns of substantive and procedural justice: concerns with both the letter and spirit of the law, concerns with procedural guarantees of fairness and accuracy in decision-making, and so forth.

Because they place law and ordinary moral reasoning in separate fields, each of these constructions has a potentially dispiriting quality. The presentation of professional responsibility as a body of self-contained legal doctrine makes Charles Fried's question-Can a good lawyer be a good person ${ }^{133}$ - a real and interesting question. When law and morality are separate, the answer to Fried's question is "yes, but not necessarily."134 Practicing law

131. Simon, supra note 60 , at 102-03. David Luban's critique of Simon's position highlights the difference between the second and third constructions described in the text. Luban criticizes Simon's emphasis on law and legal analysis in the ethical sphere, arguing that "exactly to the extent that legal reasoning is a self-contained collection of argumentative techniques, it drifts away from the moral emotions, one of our indispensable cognitive resources." Luban, supra note 122, at 900 . In contrast to Simon's position, Luban's argument relies on a distinction or difference between law and morality, and a view that the latter can be used in aid of the former. But see David Luban, Legal Ideals and Moral Obligations: A Comment on Simon, 38 WM. \& MARY L. REv. 255, 264-65 (1996) (arguing that many of the conflicts Simon sees in law/law terms can be restated as morality/morality conflicts).

132. As David Luban has observed, "Simon's is a law-centered theory. The values he wants lawyers to further are legal values; the justice he means them to pursue is legal justice." Luban, supra note 122, at 874.

133. Fried, supra note 103 , at 1060.

134. Anthony Kronman has offered an interesting response with his construction of the attorney as a "lawyer-statesman." KRONMAN, supra note 94, at 1114 and passim. The good lawyer, in Kronman's view, is a "connoisseur" of the law. Id. at 139. That is, the good lawyer cares "about the law's well being." Id. Such a lawyer views a client's situation not from the perspective of the client's 
as a neutral partisan, the lawyer will sooner or later, in great or small ways, practice local injustices toward opposing parties, toward third parties, toward the public. How is the lawyer to understand the moral significance of those injustices? She can maintain an irrational faith in an invisible hand guiding those local injustices toward the realization of a greater justice in the long run. Or she can psychologically separate her "true self" from the "professional self" who perpetrates injustices and, if successful in that separation, become alienated from her work. Or she can come to accept herself as having become an unjust person. Even if she adopts the attitude of ethicists, such as Luban by foreswearing neutral partisanship and becoming a "moral activist," she understands herself to be reaching outside the law to maintain fidelity to extralegal ethical considerations. What are the psychological costs of practicing a profession that cannot on its own terms reliably provide a moral justification for that practice? And if she adopts Simon's point of view, ${ }^{135}$ she still finds herself as a lawyer standing across a divide from those principles of ordinary morality that have not been absorbed into law and transformed into law.

We must remember, accordingly, that for all their differences, each of these three constructions presents professional responsibility as a "field" of law. Their salient common feature is that each construction more or less replicates the Langdellian vision of law as an autonomous discipline, subdivided in turn into relatively autonomous fields. Indeed, it is remarkable that professional responsibility scholars on the right and the leftfrom the most ardent defenders of the neutral partisanship model to the most trenchant critics of the status quo-seem to

narrowly defined self-interest, but from a carefully balanced point of view that considers "the good of the legal order as a whole, the good of the community that the laws establish and affirm." Id. at 141. It would seem for Kronman, then, that being a good lawyer is a way of being a good person and being a good person is necessary to being a truly good lawyer. And yet Kronman curiously and tellingly separates the demands of competence as a lawyer-statesman from the demands of professional responsibility. He argues that a good lawyer will sometimes advise a client to bring nuisance suits and breach contracts and justifies this by concluding that "within the bounds of what lawyers are ethically permitted to do, cases arise in which there is a divergence between the client's well-being and that of the law itself." Id. at 144. Once again the client's wellbeing, narrowly construed, trumps, and once again morally suspect conduct is uncontroversially seen as permitted by the relevant doctrines of professional ethics.

135. Simon prefaces Fried's question with the following: Can "a person who follows the Dominant View . . be a good lawyer?" Simon, supra note 60, at 17. 
accept the separateness of law, seem driven to replicate a version of the original Langdellian vision of law. ${ }^{136}$

By presenting professional responsibility as a field of law, each of these constructions places distinctively legal materials and legal modes of reasoning at the core of the field. Other disciplines, including ethics, with their distinctive materials and modes of reasoning, are understood to be outside of law. ${ }^{137}$ The differences among the three constructions reflect different relationships between law and the external disciplines-in the case of professional responsibility, the relationship between the law of professional responsibility and ethics. In the first construction, which most closely resembles Langdell's original vision, law is autonomous in the sense of being separate from other disciplines and rejecting the relevance of those disciplines to legal questions. Accordingly, professional responsibility is separate from ethics and rejects its relevance in the analysis of professional responsibility issues. In the second construction, law is separate from other disciplines, but may borrow from those disciplines to supplement the legal analysis. Accordingly, professional responsibility in this construction may borrow from ethics when the legal doctrine runs out or when it seems to yield unacceptable answers to professional responsibility questions. In the third construction, law reasserts its autonomy by colonizing other disciplines and absorbing and transforming them into law. Accordingly, professional responsibility absorbs a part of ethics and makes it a part of the legal material.

This consistent treatment of law and professional responsibility as bounded fields, distinguishable from ethics as a separate bounded field, has an important consequence: it leads students, practitioners, teachers, and scholars to ask about and puzzle over the relationship between the practice of law and morality. This is a question that only makes sense when law (including the law of professional responsibility) and morality are constructed as different fields.

136. Clearly, the notion that law is a separate, even autonomous discipline, is an idea of enormous and enduring power. Legal scholars at least since Langdell have, with some notable exception, insisted on law's separateness, making clear that even when law can make use of the teachings of ethics, economics, sociology, political science, and the like, it will reach outside of the law to borrow from those distinct disciplines. At the same time, when non-legal scholars criticize the state of the legal profession or of legal scholarship, they tend to accept the separateness of law. That is, they argue that legal theory and legal practice needs supplementation from disciplines outside the law in order to humanize, moralize, rationalize, or in some other way improve law. See generally Baron, supra note 90, at 21 .

137. See id. 
But to take this question seriously is to problematize the role of morality in the practice of law. And that consequence might well be among the sources of much of the public's disenchantment with the legal profession ${ }^{138}$ and of much of the alienation from their work reported by so many practitioners. Indeed, it seems to us a sad irony that even heroic attempts by scholars, such as Luban and Simon to reinvigorate legal ethics paradoxically perpetuate the deep problem of separating the "legal" from the "ethical."

Whether a different approach would improve things, we cannot know. But suppose we constructed law in a way that does not banish ordinary morality from consideration (the first construction) or require us to step outside the law to appeal to ordinary morality (the second construction) or transform ordinary morality into substantive and procedural legal materials (the third construction). Suppose we think about professional responsibility not as a bounded field, but as the idea that a good lawyer must be a good person in the ordinary understanding of that phrase. Suppose we think that the competencies we have learned in our lives-reasoning competencies, strategic competencies, and moral competencies-need not be left behind when we enter the law school as first-year law students or join a law firm. Could we then stop asking about the relationship between ordinary ethics and professional ethics, but just assume that they were one and the same? Could we believe that one could not be a good lawyer without being a good person-that being a good lawyer was just a particular way of being a good person?

If we could do these things, would anything be different? We do not know. In Part II we suggested how, such a construction might transform our understanding of ordinary lawyer tasks such as framing issues and interpreting doctrine. But perhaps instantiating ordinary ethics in the practice of law would, in the end, still generate the familiar ideas about confidentiality and conflict-of-interests, and loyalty, and the like. Perhaps we would still think it proper to defeat a just claim by raising the statute of limitations. Perhaps the public would still distrust lawyers as much as ever. Perhaps lawyers would still think of law as a game. Perhaps not.

\section{CONCLUSION}

The reader who has followed us this far might be puzzled by certain matters left unexplained. What, for example, do we

138. See supra note 101 and accompanying text. 
mean by "morality"? Morality has been central to the discussion, but we have refrained from defining the term. Had we defined morality, the definition would have implied a boundary distinguishing morality from what it is not, and that boundary would have simply reproduced the very problem of "inside" and "outside" that we have sought to identify and illuminate. Of course, any use of the term "morality," insofar as the use is intelligible, implies a definition and corresponding boundary, and our use of the term in this essay is no exception. Suffice it to say that we understand morality to include everything having to do with the question of how human beings ought to be treated-by individuals, by social groups, or by the government. Such a capacious understanding of morality includes matters that might be alternatively described as "political" or "ideological" or "legal." Accordingly, from our point of view, one virtue of our understanding of morality for purposes of this article is that it allowed us (usefully, we think) to avoid those distinctions at this stage of our inquiry.

The reader might also want to know who we think is doing all of the "constructing" at issue in the essay. We have avoided this question, too. For the issue of how social practices like law are constructed is enormously complex and beside the point we wished to make, which is about the consequences of different constructions of law. Parts of the foregoing discussion may have suggested a belief that individuals (such as Langdell or Luban or Simon) can simply decide how law and its relationship to morality should be constructed. But the understanding of law that individuals start with and the possible changes that they can envision are themselves, we believe, products of complex historical, social, psychological, and for all we know, biological forces. We do not believe, for example, that the law school construction of law, notwithstanding its association with Langdell, was the product of one man's mind or of a conspiracy between law school faculties and the organized bar. Indeed, an important part of our concern in this essay has been the enormous power of a well entrenched construction of professional responsibility to channel even the most imaginative and radically intentioned thinking in the field to replicate the entrenched construction. In any event, it was not our objective in this essay to even begin to unpack the forces generating the dominant construction or any other construction of law or of the particular field of professional responsibility.

Finally, the reader might ask at this point, "Well, what are you proposing?" In a narrow sense, as we noted in the Introduction, we are not proposing anything. Our immediate goal in this 
essay is not to reorient the field of professional responsibility. It is, rather, to observe how the field is currently constructed and identify some of the implications of that construction. In that regard, we think it important to note explicitly the extent to which the field of professional responsibility, as currently constructed, displays an openness to (if not a longing for) the possibility of minimizing responsibility.

But as we also noted in the Introduction, we do not claim to be neutral on the question of constructing the field of professional responsibility. We have not focused on this issue out of idle curiosity. We believe that the different constructions of law and professional responsibility have important consequences. Among those consequences is this: for people who care about morality, any human activity that affects the well-being of other human beings - and that includes the practice of law-will have weighty moral significance. What morality specifically requires is always subject to debate, and so what morality specifically requires of lawyers will be subject to debate. Our point is a broader one: for people who care about morality, the hegemony of a construction of law and professional responsibility that separates law from morality and separates the field of professional responsibility from ethics will generate a deep dissonance. If they are members of the general public who both seek and judge the conduct of lawyers, their attitude toward the legal profession is likely to be ambivalent; if they are members of that profession, they are likely to experience alienation.

We care about how the public views our profession, and we care about the well-being of our students and professional colleagues. Most importantly, like the myriad lawyers, scholars, teachers, and students who have wrestled with the meaning of professional responsibility, we care about morality. And we reject the dominant construction of professional responsibility. Because of its hegemony in the field, we doubt that at this time any true alternative to that construction can take hold. What is needed at this moment is incisive and relentless critique. Accordingly, we believe that a construction of professional responsibility that encourages a flight from responsibility should be continuously challenged, that the borders erected by that construction between professional responsibility and ethics should be continuously assaulted, and that the hegemony of the dominant construction should be continuously subverted. 